\title{
Deciphering the Translation Initiation Factor 5A Modification Pathway in Halophilic Archaea
}

\author{
Laurence Prunetti, ${ }^{1}$ Michael Graf, ${ }^{2,3}$ Ian K. Blaby, ${ }^{1}$ Lauri Peil, ${ }^{4}$ \\ Andrea M. Makkay, ${ }^{5}$ Agata L. Starosta, ${ }^{2,3}$ R. Thane Papke, ${ }^{5}$ Tairo Oshima, ${ }^{6}$ \\ Daniel N. Wilson, ${ }^{2,3}$ and Valérie de Crécy-Lagard ${ }^{1}$ \\ ${ }^{1}$ Department of Microbiology and Cell Science, Institute for Food and Agricultural Sciences and Genetic Institute, \\ University of Florida, P.O. Box 110700, Gainesville, FL 32611-0700, USA \\ ${ }^{2}$ Gene Center and Department for Biochemistry, University of Munich, 81377 Munich, Germany \\ ${ }^{3}$ Center for Integrated Protein Science Munich, University of Munich, 81377 Munich, Germany \\ ${ }^{4}$ Faculty of Science and Technology, Institute of Technology, University of Tartu, Tartu, Estonia \\ ${ }^{5}$ Department of Molecular and Cell Biology, University of Connecticut, 91 N. Eagleville Rd, Storrs, CT 06269, USA \\ ${ }^{6}$ Institute of Environmental Microbiology, Kyowa Kako Co. Ltd., Tadao 2-15-5, Machida 194-0035, Japan
}

Correspondence should be addressed to Laurence Prunetti; lprunetti@ufl.edu and Valérie de Crécy-Lagard; vcrecy@ufl.edu

Received 7 September 2016; Revised 27 October 2016; Accepted 6 November 2016

Academic Editor: Michael Ibba

Copyright (C) 2016 Laurence Prunetti et al. This is an open access article distributed under the Creative Commons Attribution License, which permits unrestricted use, distribution, and reproduction in any medium, provided the original work is properly cited.

\begin{abstract}
Translation initiation factor 5A (IF5A) is essential and highly conserved in Eukarya (eIF5A) and Archaea (aIF5A). The activity of IF5A requires hypusine, a posttranslational modification synthesized in Eukarya from the polyamine precursor spermidine. Intracellular polyamine analyses revealed that agmatine and cadaverine were the main polyamines produced in Haloferax volcanii in minimal medium, raising the question of how hypusine is synthesized in this halophilic Archaea. Metabolic reconstruction led to a tentative picture of polyamine metabolism and aIF5A modification in Hfx. volcanii that was experimentally tested. Analysis of aIF5A from $H f x$. volcanii by LC-MS/MS revealed it was exclusively deoxyhypusinylated. Genetic studies confirmed the role of the predicted arginine decarboxylase gene (HVO_1958) in agmatine synthesis. The agmatinase-like gene (HVO_2299) was found to be essential, consistent with a role in aIF5A modification predicted by physical clustering evidence. Recombinant deoxyhypusine synthase (DHS) from S. cerevisiae was shown to transfer 4-aminobutyl moiety from spermidine to aIF5A from Hfx. volcanii in vitro. However, at least under conditions tested, this transfer was not observed with the $H f x$. volcanii DHS. Furthermore, the growth of $H f x$. volcanii was not inhibited by the classical DHS inhibitor GC7. We propose a model of deoxyhypusine synthesis in Hfx. volcanii that differs from the canonical eukaryotic pathway, paving the way for further studies.
\end{abstract}

\section{Introduction}

The translation initiation factor 5A (IF5A) is highly conserved in Eukaryotes (eIF5A) and Archaea (aIF5A), whereas bacteria harbor the homolog elongation factor P (EF-P). IF5A performs multiple intracellular functions and is involved in cell growth and death $[1,2]$. While both eIF5A and EF-P proteins had been initially linked to translation initiation $[1,3]$, recent studies have shown that they are required for the efficient translation of proteins containing polyproline stretches (Pro-Pro-Pro; Pro-Pro-Gly) [4-10].
Major differences between IF5A and EF-P exist, even if their core function in translation is conserved. First, both eIF5A and aIF5A are essential [11, 12] whereas deletion of bacterial efp can be viable and leads to a range of phenotypes depending on the organism [13-16]. Second, the posttranslational modification of a strictly conserved lysine (K50, Human eIF5A) into $\mathrm{pN}^{\varepsilon}$-(4-amino-2hydroxybutyl)lysine or hypusine is required for eIF5A activity and the hypusine modification pathway is conserved in Eukaryotes [11]. Conversely, hypusine is not found in the bacterial EF$\mathrm{P}$ proteins where the equivalent lysine can be modified by the 
addition of a $\beta$-lysine residue [17-21] or by rhamnosylation $[22,23]$.

The eukaryotic hypusine synthesis pathway contains two consecutive steps [11, 24-27]. The first enzyme, deoxyhypusine synthase (DHS), catalyzes the transfer of the 4aminobutyl moiety of spermidine to the target lysine residue forming the deoxyhypusine intermediate [26]. This intermediate is then hydroxylated by deoxyhypusine hydroxylase (DOHH) to form the biologically active hypusinylated factor [11]. $\mathrm{N}^{1}$-Guanyl-1,7-diaminoheptane (GC7), a spermidine homolog, very efficiently inhibits the first step of hypusination by binding to DHS $[28,29]$. In Eukaryotes, the hypusine modification of eIF5A occurs shortly after the synthesis of eIF5A and no pool of unmodified proteins has ever been detected [30, 31]. Interestingly, although the deoxyhypusine/hypusine modification is essential in all eukaryotes, only DHS is essential in Saccharomyces cerevisiae and eIF5A partially modified with deoxyhypusine is functional $[1,3]$.

The archaeal aIF5A proteins and their modification pathways are poorly characterized. DHS homologs are present in all sequenced archaeal genomes; however to date, no DOHH orthologue has been identified in any archaeal genomes or proteomes $[25,26]$, raising questions about the nature of this final modification in Archaea. Early analyses based on amino acid composition data reported the presence of both hypusine and deoxyhypusine in Archaea [32]. Hypusine was detected in several Crenarchaea like Sulfolobus acidocaldarius, Pyrodictium occultum, Thermoproteus tenax, and Acidianus ambivalens. However, high levels of deoxyhypusine but no (or only low levels) traces of hypusine were found in Euryarchaeota (i.e., halobacteriales, methanogen, thermococcales, and thermoplasmales) [32] and the specific nature of the modification found in aIF5A proteins was never confirmed by mass-spectrometry (MS) methods. Growth inhibition by GC7 has been reported in four archaeal species S. acidocaldarius, Sulfolobus solfataricus, Halobacterium halobium DSM 670, and Haloferax mediterranei DSM1411 [33], suggesting that the archaeal deoxyhypusine pathway is essential, as in eukaryotes. S. acidocaldarius aIF5A is to date the only archaeal protein for which the presence of the hypusine modification has been experimentally confirmed by amino acid composition [34]. The presence of the DHS encoding genes in archaeal genomes, combined with the GC7 inhibition results, strongly suggests that deoxyhypusine is synthesized by similar mechanisms in Archaea and Eukarya, yet many questions remain.

Spermidine is the 4-aminobutyl donor for the eukaryotic DHS enzyme [11] but the great diversity of polyamines found in Archaea suggests this might not always be the case in this kingdom of life. Indeed, spermidine was detected in Thermococcus kodakarensis [35] and in various Sulfolobus species [36] and homospermidine (that could also be an aminobutyl donor for DHS [37]) was found to be an abundant polyamine in methanogens [38] (Table S1). However, the composition of intracellular polyamines was analyzed in 117 archaeal halophiles strains and trace amounts of spermidine and/or spermine were detected in only 20 strains [39]. Agmatine appears to be the major accumulating polyamine in this order (Table S1 in Supplementary Material available online at http://dx.doi.org/10.1155/2016/7316725) [36, 40, 41]. Agmatine is the precursor of agmatidine, an essential modification of the anticodon wobble cytosine in archaeal tRNA ${ }^{\mathrm{Ile}}$ CAU $[42-$ 44]. Agmatine is therefore an essential archaeal metabolite that can be either synthesized de novo or salvaged [42]. More generally, while archaeal polyamine metabolic pathways have been partially elucidated in thermophilic Archaea [35, 45], litthe is known about polyamine pathway in halophilic Archaea.

By combining metabolic reconstruction, genetics, comparative genomics, and biochemical studies, we set out to elucidate both the polyamine and aIF5A modification pathways in the model halophile Haloferax volcanii.

\section{Experimental Procedures}

2.1. Strains and Growth Conditions. All strains, plasmids, and oligonucleotides used in this study are listed in Tables S2 and Table S3. Hfx. volcanii $\mathrm{H} 26$ was used as the parent strain. Escherichia coli derivatives were routinely grown in LB-Lennox (LB) (Fisher) or LB agar (Fisher) at $37^{\circ} \mathrm{C}$ and supplemented when required with ampicillin (Amp, $100 \mu \mathrm{g} / \mathrm{mL}$ ). $H f x$. volcanii strains were grown at $42^{\circ} \mathrm{C}$ in either rich (ATCC 974) or minimal media (Hv_min) as previously described [46]. Novobiocin $(0.1 \mu \mathrm{g} / \mathrm{mL})$ and agar $(5 \mathrm{~g} / \mathrm{L})$ were included as needed. Uracil was dissolved to $50 \mathrm{mg} / \mathrm{mL}$ in $100 \%(\mathrm{v} / \mathrm{v})$ DMSO and added to growth medium at a final concentration of $50 \mu \mathrm{g} / \mathrm{mL}$. Transformations of E. coli and Hfx. volcanii were performed as previously described [46].

\subsection{Plasmid and Strain Constructions}

2.2.1. HVO_1958 and HVO_2299 Deletions. Plasmids used to delete the HVO_1958 and HVO_2299 genes were constructed as described previously [44]. Briefly, $\sim 600 \mathrm{bp}$ regions upand downstream of HVO_1958 and HVO_2299 were PCRamplified from purified genomic DNA using Phusion polymerase (NEB) and the oligonucleotides listed in Table S3 and then inserted using In-Fusion (Clontech) into pTA131, linearized by digestion with EcoRI and XhoI. The resulting plasmids, pIKB313 and pIKB298, containing the deletion constructs for HVO_1958 and HVO_2299, respectively, were validated by sequencing before passaging through $E$. coli Inv110 (Invitrogen). The plasmids were subsequently transformed into Hfx. volcanii strain $\mathrm{H} 26$, and the deletion strains were generated by the pyrE2-based "pop-in/pop-out" deletion method $[47,48]$, with standard media preparations [46] except that the media was supplemented with $100 \mu \mathrm{M}$ agmatine for deletion of $\mathrm{HVO} 1958$ or with or without $1 \mathrm{mM}$ putrescine for the deletion of HVO_2299. Deletion of HVO 1958 was validated by PCR methods using the primers ext $\mathrm{f}$ and ext $\mathrm{r}$ (Table S3), generating strain VDC3253 (Table S2).

2.3. LSP5061. H26 was transformed with pIKB298 and the pop-in was generated $[47,48]$ with standard media preparation. Ten isolated colonies of the pop-in were pooled together and grown in liquid to generate competent cells [47]. The competent "pop-in strain" was transformed with the 
pLSP21 plasmid that was constructed by cloning HVO_2299 under the control of the $\mathrm{P}_{\text {TNA }}$ promoter into the pJAM202 derivative pPT002 (Table S2) in the presence of $2.5 \mathrm{mM}$ tryptophan and novobiocin $(0.1 \mu \mathrm{g} / \mathrm{mL})$ before generating the pop-out (LSP5061) in presence of $2.5 \mathrm{mM}$ tryptophan and novobiocin $(0.1 \mu \mathrm{g} / \mathrm{mL})$ [49]. Deletion of $H V O \_2299$ from the $H f x$. volcanii genome was validated by PCR methods using the primers FW-391 and RV-391 (Table S3).

2.3.1. TIF5A-C-Term His Integrant. VDC2577, containing the native copy of aIF5A (HVO_2300) with a C-terminal His-tag (6x His), was generated by transformation of Hfx. volcanii H26 with pIKB473 (Table S2), constructed as described in previously [44], with the oligonucleotides listed in Table S3.

\subsection{Physiology Studies}

2.4.1. Stress Conditions. Cells were subjected to different stress conditions as described in [50]. Briefly, H26 were inoculated into $5 \mathrm{~mL}$ ATCC 974 and then diluted into $25 \mathrm{~mL}$ of fresh ATCC 974 at $\mathrm{OD}_{600}$ of 0.0074 . The cells were grown at $42^{\circ} \mathrm{C}$ for 24 hours in order to reach early exponential growth phase $\left(\mathrm{OD}_{600}=1.29 \pm 0.049\right)$ before the stress was applied for 4 hours (oxidative and cold shock) or 24 hours (proteasome inhibitor). Oxidative stress was induced by the addition of $\mathrm{H}_{2} \mathrm{O}_{2}$ to a final concentration of $0.78 \%$ (w/v) for 4 hours at $42^{\circ} \mathrm{C}$ with shaking $(200 \mathrm{rpm})$. For cold shock, the cells were grown at $30^{\circ} \mathrm{C}$ for 4 hours with shaking (200 rpm). The proteasome inhibitor, bortezomib (LC Laboratories), was added at $100 \mu \mathrm{M}$ final concentration as described in [51]. Cultures were incubated with shaking $(200 \mathrm{rpm})$ at $42^{\circ} \mathrm{C}$ for 24 hours. After the stress, growth was monitored and $2 \mathrm{~mL}$ of culture at an $\mathrm{OD}_{600} 0.043$ was harvested for immunoblot analysis.

2.4.2. Culture in Presence of GC7. To monitor the effect of $\mathrm{N}^{1}$-guanyl-1,7-diaminoheptane (GC7) (Santa Cruz Biotechnologies) on $H f x$. volcanii growth, $\mathrm{H} 26$ was inoculated into $5 \mathrm{~mL}$ of ATCC 974 medium and grown to log phase. Cells were subcultured into $5 \mathrm{~mL}$ of fresh Hv_min medium until exponential phase. The cells $\left(1 \mathrm{~mL}\right.$ at an $\left.\mathrm{OD}_{600}=1\right)$ were washed 4 times in Hv_min medium and serial dilutions in Hv_min medium were spot-plated $(15 \mu \mathrm{L})$ onto solid Hv_min agar in the absence or presence of $1 \mathrm{mM}$ GC7. The cells were grown at $45^{\circ} \mathrm{C}$ for 4 days. The experiments were done with two biological replicates (i.e., two independent cultures) and three technical duplicates (three measurements per culture).

2.4.3. Culture in Presence of Agmatine. Hfx. volcanii H26 (WT, parent) and $\Delta a d c$ (VDC3253) were grown in $5 \mathrm{~mL}$ ATCC 974 medium supplemented with $\mathrm{mM}$ agmatine at $42^{\circ} \mathrm{C}$. Cells were then subcultured into $5 \mathrm{~mL} \mathrm{Hv \_ min} \mathrm{medium}$ at $42^{\circ} \mathrm{C}$. Cells grown to stationary phase (after 48 hours at $42^{\circ} \mathrm{C}$ ) were washed 4 times in Hv_min medium. Cell density was normalized by dilution to $\mathrm{OD}_{600}$ of 1 and serial dilutions were spot-plated $(15 \mu \mathrm{L})$ on solid agar Hv_min medium in the absence or presence of agmatine $(1 \mu \mathrm{M}$ or $5 \mu \mathrm{M})$. Each experiment was performed with two biological replicates and three technical replicates.

\subsection{Polyamines Analyses}

2.5.1. Sample Preparation. $\mathrm{H} 26$ was grown in $1 \mathrm{~L}$ of $\mathrm{Hv} \_$min medium in $2.8 \mathrm{~L}$ Fernbach flasks at $42^{\circ} \mathrm{C}(200 \mathrm{rpm})$. At different points of growth (early exponential $\mathrm{OD}_{600}=0.0805$, mid-exponential $\mathrm{OD}_{600}=0.86$, and late exponential $\mathrm{OD}_{600}$ $=1.2$ ), cells were harvested at 5,500 rpm (SLA 3000, Sorvall) for $40 \mathrm{~min}$ at $4^{\circ} \mathrm{C}$ and then washed with $50 \mathrm{mM}$ HEPES, $2 \mathrm{M} \mathrm{NaCl}$, and $\mathrm{pH} 8$ buffer. The pellets were frozen in liquid nitrogen prior to desiccation. Experiments were done with two biological replicates.

2.5.2. Polyamines Extraction. An appropriate amount of the cells (between 7 and $110 \mathrm{mg}$ ) was transferred into an Eppendorf tube and suspended in $1 \mathrm{~mL}$ of $10 \%$ trichloroacetic acid solution. The suspension was shaken for 1 min repeatedly and kept at room temperature overnight. The suspension was then centrifuged and the supernatant was filtered using $0.2 \mu \mathrm{m}$ membrane filter in order to remove fine dust. The filtrate was diluted in water if necessary and applied on a polyamine analyzer.

2.5.3. Polyamines Analysis. Polyamines were analyzed with a CK10S column $(8.0 \times 70 \mathrm{~mm}$, Mitsubishi Kasei $)$ as described previously [52]. Briefly, the column was developed with Type 2 buffer (citrate buffer containing $125 \mathrm{~g} / \mathrm{L}$ of $\mathrm{KCl}$ ) at $60^{\circ} \mathrm{C}$, at a flow rate of $2 \mathrm{~mL} / \mathrm{min}$. Polyamines were detected using $o$-phthalaldehyde and fluorescence at $\lambda 450 \mathrm{~nm}$ (excitation at $\lambda 340 \mathrm{~nm}$ ) was recorded. The recorded chart was analyzed as described previously [52]. For each biological sample, two technical replicates were analyzed. The standard used was a mixture of $2.0 \mu \mathrm{M}$ agmatine and $2.8 \mu \mathrm{M}$ cadaverine.

\subsection{Protein Purification}

2.6.1. aIF5A-His-C-Term Purification. E. coli Rosetta gami 2 (DE3) (Novagen) strains freshly transformed with plasmid pLSP24 were grown in $1 \mathrm{~L} \mathrm{LB} \mathrm{Amp} \mathrm{in} 2.8 \mathrm{~L}$ Fernbach flasks at $37^{\circ} \mathrm{C}(200 \mathrm{rpm})$ in the presence of $2 \%$ glucose. Isopropyl $\beta$-D-1-thiogalactopyranoside (IPTG) was added to a final concentration of $0.4 \mathrm{mM}$ at $\log$ phase $\left(\mathrm{OD}_{600}\right.$ of 0.4-0.6 units), and cultures were shifted to $25^{\circ} \mathrm{C}$ for 3 hours $(200 \mathrm{rpm})$ prior to harvest. Cells were harvested by centrifugation $\left(5,000 \times \mathrm{g}, 4^{\circ} \mathrm{C}, 15 \mathrm{~min}\right)$ and stored at $-80^{\circ} \mathrm{C}$. Cells (10-gram wet weight) were resuspended in $20-25 \mathrm{~mL}$ of $20 \mathrm{mM}$ Tris- $\mathrm{HCl} \mathrm{pH} 8$ and $2 \mathrm{M} \mathrm{NaCl}$ (buffer A) and broken by passage three times by French Press at a pressure of 2000 psi. After $15 \mathrm{~min}$ of centrifugation at $3,000 \times \mathrm{g}\left(4^{\circ} \mathrm{C}\right)$ to remove unbroken cells, the supernatant was filtered through a $0.8 \mu \mathrm{M}$ cellulose acetate membrane (Fisher Scientific, USA). The supernatant was then applied to a HisTrap HP column (1 mL, GE Healthcare) preequilibrated with buffer A with $40 \mathrm{mM}$ imidazole and washed with the same buffer at room temperature. aIF5A-C-term His-tag protein was eluted from the column with $20 \mathrm{mM}$ Tris- $\mathrm{HCl} \mathrm{pH} 8,2 \mathrm{M} \mathrm{NaCl}$, and $500 \mathrm{mM}$ imidazole (buffer B). Purified proteins were detected by Western blotting and/or Coomassie Blue R-250 staining after separation by $10 \%$ SDS-PAGE. The purified proteins 
were precipitated by trichloroacetic acid (TCA) as described by Sanchez [53] before loading on SDS-PAGE.

2.6.2. T7-His-DHS. Hfx. volcanii LSP5021 (H26 carrying pLSP23) was used for the purification of T7-His-DHS. LSP5021 (40-gram wet weight) were resuspended in $80 \mathrm{~mL}$ of buffer $A$ and broken by passage three times through a French Press at a pressure of $2000 \mathrm{psi}$ as described before. Briefly, the supernatant was applied to a HisTrap HP column $(5 \mathrm{~mL}, \mathrm{GE}$ Healthcare). Then the fraction was dialyzed overnight against $1 \mathrm{~L}$ of buffer $\mathrm{A}$. The sample was applied to a hydroxyapatite column (HTP) $(25 \mathrm{~mL})$ preequilibrated with buffer A at flow rate of $1 \mathrm{~mL} / \mathrm{min}$ and eluted with a continuous gradient of Tris- $\mathrm{HCl} 20 \mathrm{mM}, 2 \mathrm{M} \mathrm{NaCl}$, and $400 \mathrm{mM}$ sodium phosphate $\mathrm{pH}$ 8. Fractions of $1 \mathrm{~mL}$ were collected. The T7-His-DHS was eluted from the column with $40 \mathrm{mM}$ of sodium phosphate in buffer A. The eluate was concentrated (Vivaspin 3,000 Dalton molecular weight cut off, Sartorius Stedim Biotech) and applied to a Sephacryl S-200 HR gel filtration column equilibrated with buffer $A$ at a flow rate of $0.3 \mathrm{~mL} / \mathrm{min}$. Fractions of $1 \mathrm{~mL}$ were collected.

2.6.3. Purification of IF5A and DHS from Saccharomyces cerevisiae and Thermococcus kodakarensis. The coding sequences of the respective proteins were cloned into pET28a $(+)$ vector with an additional (6x) His-tag and TEV cleavage site using oligo pairs depicted in the supplemental data (Table S3). Proteins were overexpressed in BL21 E. coli cells grown at $37^{\circ} \mathrm{C}$ from overnight culture in LB in presence of $50 \mu \mathrm{g} / \mathrm{mL}$ kanamycin. Protein expression was induced at $\mathrm{OD}_{600}$ of 0.4 with a final concentration of $1 \mathrm{mM}$ IPTG (Roth). After 1 hour of expression cells were lysed using a microfluidizer (Microfluidizer Processor Microfluidics Newton, USA). The cell lysate was cleared using a SS34 rotor (Sorvall) at $4^{\circ} \mathrm{C}$ and $44,100 \times \mathrm{g}$ for $30 \mathrm{~min}$. Purification of His-tagged proteins was done with Protino Ni-NTA agarose beads (Macherey-Nagel). The final eluate was applied onto a Superdex HiLoad S75 $16 / 60$ column (GE Healthcare) to yield the final concentrated protein in gel filtration buffer (50 mM HEPES $\mathrm{pH}$ 7.4, $50 \mathrm{mM}$ $\mathrm{KCl}, 100 \mathrm{mM} \mathrm{NaCl}$, and $5 \mathrm{mM}$ 2-mercaptoethanol).

\subsection{Deoxyhypusine Synthase Assay}

2.7.1. Thermococcus kodakarensis. DHS modification assay was performed in presence of either $75 \mu \mathrm{M}$ radioactive $\left[{ }^{14} \mathrm{C}\right]$ spermidine trihydrochloride (GE Healthcare) or $3 \mu \mathrm{M}$ putrescine dihydrochloride $\left[1,4{ }^{3} \mathrm{H}(\mathrm{N})\right]$ (Perkin Elmer). The reaction mixture contained the substrates $5 \mu \mathrm{M}$ of $S$. cerevisiae eIF5A or T. kodakarensis aIF5A, as well as $2 \mathrm{mM}$ nicotinamide adenine dinucleotide $\left(\mathrm{NAD}^{+}\right), 2.5 \mu \mathrm{M} \mathrm{S}$. cerevisiae DHS, or T. kodakarensis DHS in $0.2 \mathrm{M}$ glycine- $\mathrm{NaOH}$ buffer, pH 9.4 (total volume $30 \mu \mathrm{L}$ ). After 120 minutes of incubation at $37^{\circ} \mathrm{C}$, incorporation of radiolabeled deoxyhypusine was monitored using a 16.5\% Tricine-PAGE gel, which was subsequently dried and exposed to high-performance autoradiography films (GE Healthcare). Color Prestained Broad Range Protein Standard (NEB) was used as molecular weight marker.
2.7.2. Haloferax volcanii. DHS was tested in cell extract overexpressing DHS. For DHS assay, the experiment was conducted in presence of either $75 \mu \mathrm{M}$ radioactive $\left[{ }^{14} \mathrm{C}\right]$ spermidine trihydrochloride ( $111 \mathrm{mCi} / \mathrm{mmol}$, GE Healthcare) or $3 \mu \mathrm{M}$ putrescine dihydrochloride $\left[1,4-{ }^{3} \mathrm{H}(\mathrm{N})\right](62 \mathrm{Ci} / \mathrm{mmol}$, Perkin Elmer). Each $30 \mu \mathrm{L}$ sample contained $20 \mu \mathrm{L}$ of $H f x$. volcanii extract (overexpressing DHS at a concentration of $3 \mathrm{mg} / \mathrm{mL}$ ), $5 \mu \mathrm{L}$ of $1.5 \mathrm{mg} / \mathrm{mL}$ Hfx. volcanii aIF5A, $1 \mu \mathrm{L}$ of $100 \mathrm{mM}$ nicotinamide adenine dinucleotide (NAD+), and the respective substrate. All samples were incubated at $42^{\circ} \mathrm{C}$ for 2 hours. Due to the presence of high salt concentrations in the $H f x$. volcanii extract all samples were subjected to buffer exchange (50 $\mathrm{mM}$ HEPES, $100 \mathrm{mMK}(\mathrm{OAc})$ and $25 \mathrm{mM} \mathrm{Mg}(\mathrm{OAc})$ ) via Amicon Ultra $0.5 \mathrm{~mL}$ Ultracel $3 \mathrm{~K}$ (Merck Millipore) before gel electrophoresis. The final samples were separated on a 16.5\% Tricine gel. For evaluation of the protein size Spectra Multicolor Low Range Protein Ladder (Thermo Scientific) was used. Dried gels were exposed to high-performance autoradiography films (GE Healthcare) to evaluate the occurrence of aIF5A modification by DHS in the respective sample. The control samples with $S$. cerevisiae DHS were prepared as described for the T. kodakarensis DHS assay. To test the activity of Hfx. volcanii T7-His-DHS, 200 pmol of radioactive polyamines (agmatine, putrescine, or spermidine) was mixed with $20 \mathrm{pmol}$ of T7-His-DHS in the presence or absence of $100 \mathrm{pmol}$ of Hfx. volcanii aIF5A in $0.3 \mathrm{M}$ glycine- $\mathrm{NaOH} \mathrm{pH}$ 9.0, $2 \mathrm{M} \mathrm{NaCl}$, and $1 \mathrm{mM}$ NAD for 1 hour at $40^{\circ} \mathrm{C}$.

2.7.3. Synthesis of Radiolabeled Agmatine. Since radiolabeled agmatine is not available commercially, it was synthetized from $\left[{ }^{14} \mathrm{C}\right]$ arginine (Perkin Elmer) using arginine decarboxylase (SpeA). The plasmid pAS1 (carrying speA-C-termHis) was transformed into BL21 E. coli strain (Novagen) and expressed in LB media. Cultures $(200 \mathrm{~mL})$ were induced with $1 \mathrm{mM}$ IPTG at $\mathrm{OD}_{600}=0.6$ and grown for another 3 hours at $30^{\circ} \mathrm{C}$. Thirty minutes prior to induction, chaperons were induced by addition of 1\% (final concentration) of ethanol into LB media. Protein was purified using NiNTA spin columns (Qiagen) according to the manufacturer protocol, followed by buffer exchange (into $50 \mathrm{mM}$ HEPES $\mathrm{pH} 7.4,10 \mathrm{mM} \mathrm{MgCl}_{2}, 100 \mathrm{mM} \mathrm{NaCl}, 50 \mathrm{mM} \mathrm{KCl}, 5 \mathrm{mM}$ betamercaptoethanol, and 2\% glycerol) using PD10 desalting columns (GE Healthcare). Agmatine synthesis from $\left[{ }^{14} \mathrm{C}\right]$ arginine $(124 \mathrm{dpm} / \mathrm{pmol})$ by SpeA was carried out in $0.3 \mathrm{M}$ glycine- $\mathrm{NaOH} \mathrm{pH} \mathrm{9.0,10} \mathrm{mM} \mathrm{MgCl}_{2}$, and $1 \mathrm{mM} \mathrm{PLP}$ at $37^{\circ} \mathrm{C}$ for 1 hour. The progress of the reaction was monitored using Silica Plates (Merck Millipore) developed in butanol/acetic acid/pyridine/formaldehyde $3: 3: 2: 1$ and exposed to highperformance autoradiography films (GE Healthcare).

\subsection{Analytical Procedures}

2.8.1. Protein Concentration. Protein concentrations were determined by the bicinchoninic acid method [54] (Thermo Scientific Pierce BCA Protein Assay Kit, Rockford, IL) with bovine serum albumin (BioRad) as the protein standard. 
2.8.2. Electrophoresis. Protein samples were mixed in equal volume ratio with $2 \mathrm{x}$ loading buffer (containing $125 \mathrm{mM}$ Tris-HCL pH 6.8, 20 mM $\beta$-mercaptoethanol, 4\% (w/v) SDS, $20 \%(\mathrm{v} / \mathrm{v})$ glycerol, and $0.01 \%(\mathrm{w} / \mathrm{v})$ bromophenol blue) and boiled for $15 \mathrm{~min}$. Samples were separated by 12\% SDS-PAGE or gradient gel $4-15 \%$ (Biorad), using a mini-Protean III cell electrophoresis apparatus (Biorad) at $20 \mathrm{~mA}$ constant current at room temperature in a running buffer of $25 \mathrm{mM}$ Tris and $190 \mathrm{mM}$ glycine at $\mathrm{pH} 8.3$ with $0.1 \%$ (w/v) SDS. After migration, proteins were stained in-gel with Coomassie Blue R-250 or were detected by Western blotting.

2.8.3. Western Blotting. For aIF5A analysis during the growth in ATCC at $42^{\circ} \mathrm{C}, \mathrm{H} 26$ cells ( $2 \mathrm{~mL}$ at OD 0.043 of the culture) were harvested via centrifugation $\left(14,000 \times \mathrm{g}, 10 \mathrm{~min}, 25^{\circ} \mathrm{C}\right)$ and treated as described before. Proteins were separated by SDS-PAGE (gradient gel 4-15\%, Biorad) and transferred onto PVDF membrane (GE Healthcare). Equivalent protein loading was based on $\mathrm{OD}_{600}$ of cell culture (0.086 units per lane) and confirmed by staining parallel gels with Coomassie Blue. aIF5A protein was detected via immunoblot using TIF5A2 $(1 / 10,000)$ or TIF5A3 $(1 / 5,000)$, followed by a secondary anti-rabbit IgG antibody [HRP] $(1 / 5,000)$ (GenScript, USA). The rabbit polyclonal antibodies TIF5A2 and TIF5A3 were produced using, respectively, the synthetic peptides CEIEYLEYEGQRKIV and MAKEQKQVRELQEGC (GenScript, USA). Membranes were visualized via chemiluminescence using Clarity western ECL (Biorad) with X-ray film (Fisher). aIF5A C-term His was detected with the anti C-term-His-HRP (Invitrogen) at a dilution 1/5,000. The deoxyhypusine/hypusine modification was detected with the antibody IU-88 (1/1,500) as described by [55].

2.9. Mass Spectrometry. Briefly, aIF5A was in-gel digested with LysC (Wako) according to the protocol of Shevchenko et al. [56] and desalted on C18-StageTips [57]. Peptides were then separated by reversed-phase liquid chromatography (LC) on a Dionex UltiMate RSLCnano 3000 system (Thermo Fisher Scientific). LC conditions were as follows: $30 \mathrm{~min}$ 3-40\% B gradient (A: $0.1 \%$ formic acid, B: $0.1 \%$ formic acid $/ 80 \%$ acetonitrile) at a flow rate of $200 \mathrm{~nL} / \mathrm{min}$, using $75 \mu \mathrm{m} \times 300 \mathrm{~mm}$ fused silica emitter (New Objective, USA) packed in-house with Reprosil-Pur C18-AQ $3 \mu \mathrm{m}$ particles (Dr. Maisch, Germany). Eluted peptides were sprayed directly into a Q Exactive mass-spectrometer (Thermo Fisher Scientific) operated in data-dependent mode with up to ten $\mathrm{MS} / \mathrm{MS}$ scans $(\mathrm{NCE}=25)$ being recorded for each precursor ion scan. Peak lists for database search were prepared by using MSConvert. Database search was performed with the Mascot 2.3 search engine (Matrix Science) against the protein sequence database containing aIF5A sequence and common contaminant proteins, such as trypsin and keratins. Search parameters were $5 \mathrm{ppm}$ for precursor mass tolerance, $0.02 \mathrm{Da}$ for Orbitrap MS/MS mass tolerance, and up to three missed cleavages plus a number of variable modifications such as oxidation (M), hypusinylation (K), and deoxyhypusinylation (K). Peptide hits returned by Mascot were manually validated and annotated using xiSPEC (http://spectrumviewer.org/).
2.10. Bioinformatics. The gene sequences were obtained from NCBI. The BLAST tools [58] and resources at NCBI (https://www.ncbi.nlm.nih.gov/) were used routinely. Multiple sequence alignments were built using Clustal Omega [59] or MultAlin [60]. Protein domain analysis was performed using the Pfam database tools [61]. Transmembrane helices were predicted with the TMHMM Server v. 2.0 (http://www .cbs.dtu.dk/services/TMHMM-2.0/) [62]. Analysis of phylogenetic distribution and physical clustering was performed with STRING (http://string-db.org/.) [63] and the SEED Database [64].

\section{Results and Discussion}

3.1. Metabolic Reconstruction of Polyamines Metabolism and aIF5A Modification in Hfx. volcanii. Spermidine is the donor for the eukaryotic DHS enzyme [11]. In a recent review on polyamine metabolism in all kingdoms of life [37], a core starter pathway for polyamine synthesis in Archaea through the decarboxylation of arginine by arginine decarboxylase (ADC) was proposed. Metabolic reconstruction in $H f x$. volcanii indicates that most of the core biosynthetic pathway for the synthesis of spermidine is present (Figure 1(a)). Two forms of ADC are found in Archaea [37]. The first type is a pyruvoyl-dependent enzyme, and the corresponding gene (TK0149) is essential for growth of T. kodakarensis [65]. The second is a paralog of AdoMet decarboxylase (AdoMet DC) that can decarboxylate arginine, found mainly in Crenarchaeota [37]. Like T. kodakarensis, Hfx. volcanii harbors a homolog of the pyruvoyl-dependent type encoded by $H V O \_1958$ (Figure 1(a)) [66].

The next step in the proposed archaeal spermidine pathway is the formation of putrescine by hydrolysis by the agmatinase/agmatine ureohydrolase (AUH) enzyme. The AUH enzymes from Pyrococcus horikoshii and Methanocaldococcus jannaschii have been biochemically characterized $[67,68]$, but no archaeal mutant was ever constructed. An agmatinase family member, HVO_2299, is found in Hfx. volcanii and could possibly catalyze this reaction (Figure 1(a)) [66].

Finally, spermidine synthase transfers the 3-aminopropyl moiety from decarboxylated adenosylmethionine (dcAdoMet) to putrescine. Two members of the spermidine synthase family are found in Hfx. volcanii: HVO_0255 and HVO_B0357 (Figure 1(a)) [66]. Deletion of the HVO_B0357 gene did not give rise to any phenotypes under the conditions tested [44]. Interestingly, the N-terminal regions of HVO_0255 and HVO_B0357 and of halophilic homologs contain seven transmembrane domains ( $\mathrm{N}$-terminal transporter like domain) (Fig. S1A). The presence of the N-terminal transporter like domain in both of these proteins and the fact that the putrescine binding residues are not conserved in theses halophilic SpeE homologs (Fig. S1B) suggest that these proteins might have other as yet undetermined roles.

Whereas AdoMet DC is present in T. kodakarensis [69], no homologs of AdoMet DC were found in either $H f x$. volcanii or more generally any sequenced halophiles (data not shown). This raises the question of the potential source of dcAdoMet in a putative spermidine synthase reaction. 


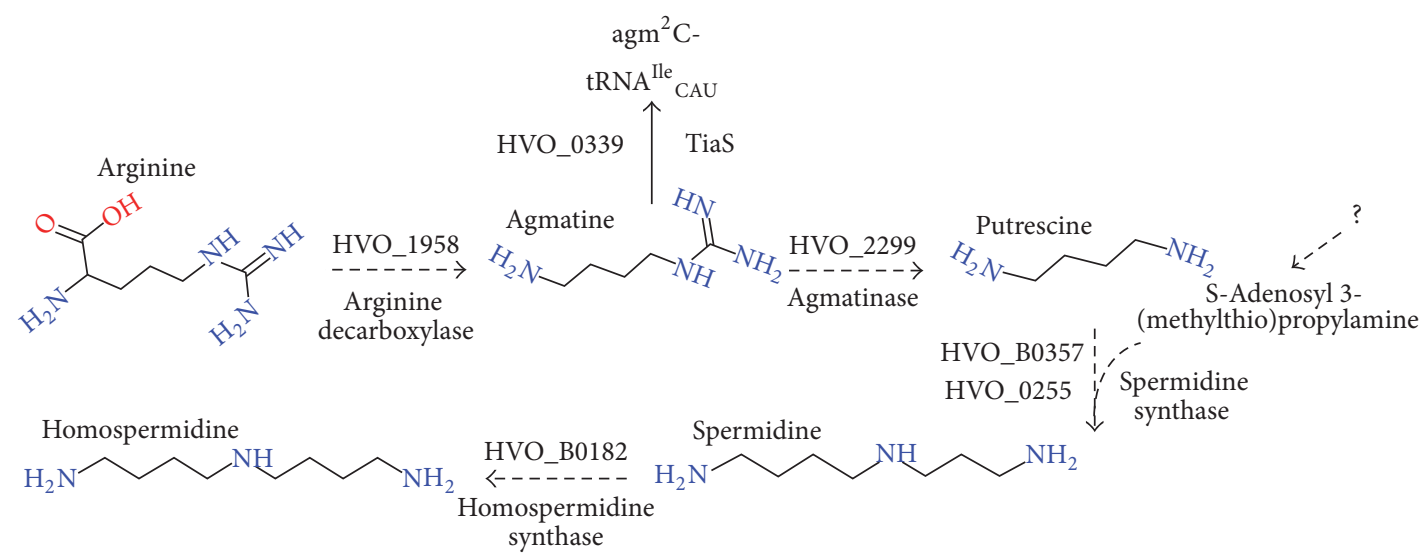

(a)

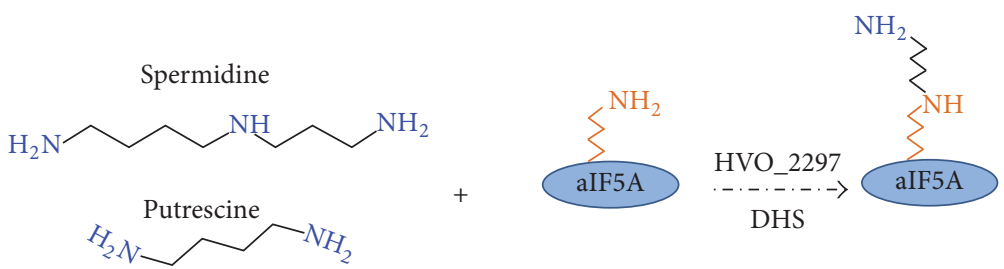

(b)
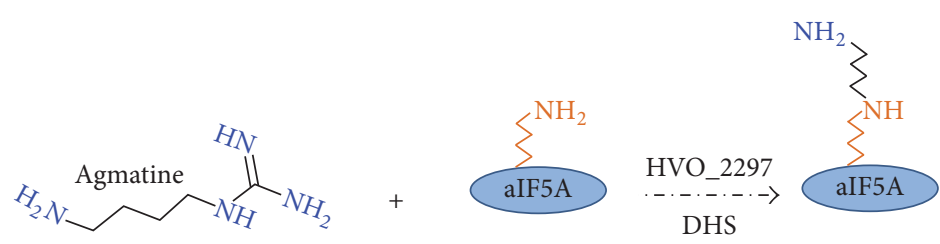

(c)

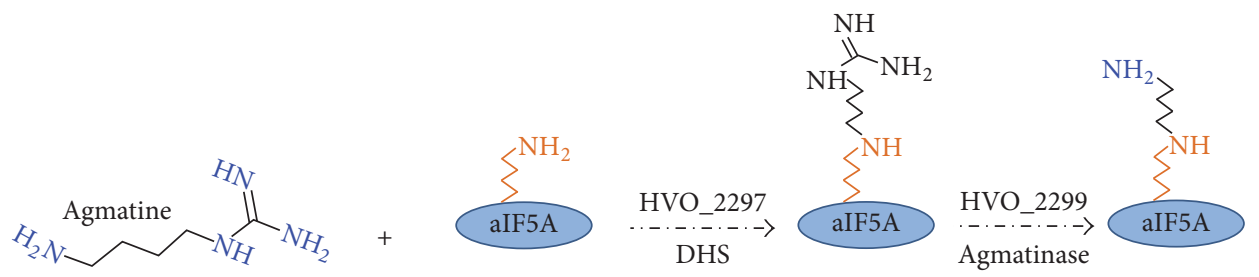

(d)

FIgure 1: Proposed models of polyamines metabolism and aIF5A in Hfx. volcanii. (a) Predicted pathways of polyamines synthesis from arginine substrate. Dashed arrows indicate proposed reaction; solid arrow indicates known reaction. (b-d) Proposed substrates of DHS. HVO_1958 encodes a potential arginine decarboxylase; HVO_2299 an agmatinase-like; HVO_0255 a spermidine synthase; HVO_B0182 a spermidine synthase or a homospermidine synthase; and HVO_2297 a potential deoxyhypusine synthase.

Other genes putatively related to polyamine metabolism in $H f x$. volcanii include the HVO_0339 gene encoding the essential agmatidine synthase TiaS (Figure 1(a)) [44] and the HVO_B0045 and $H V O \_B 0046$ genes predicted to encode L-2,4-diaminobutyrate decarboxylase and L-2,4aminobutyrate aminotransferase. It has been proposed that these two enzymes participate in the synthesis of a 1,3diaminopropane-based siderophore such as rhizobactin 1021 or schizokinen [70].

Two members of the DHS family are found in $H f x$. volcanii HVO_2297 and HVO_B0182 [66]. The HVO_2297 gene is physically clustered with the gene encoding aIF5a (HVO_2300) (Figure 2). To our knowledge, the activity of HVO_2300 (as aIF5A) has never been experimentally validated, the gene is essential [12]. Hence, HVO_2297 is a potential candidate for the canonical DHS enzyme and HVO_B0182 could be involved in homospermidine synthesis as proposed by [37] (Figure 1(a)).

As summarized in Figure 1, metabolic reconstruction gives only a tentative picture of polyamine metabolism (Figure 1(a)) and the aIF5A modification pathway (Figures 1(b), 1(c), and 1(d)) in Hfx. volcanii. DHS could transfer the aminobutyl group from spermidine to aIF5A (Figure 1(b)) but it is not clear if the spermidine pathway is present in this organism since no AdoMet DC gene could be identified (Figure 1(a)). Other possibilities already partially discussed 


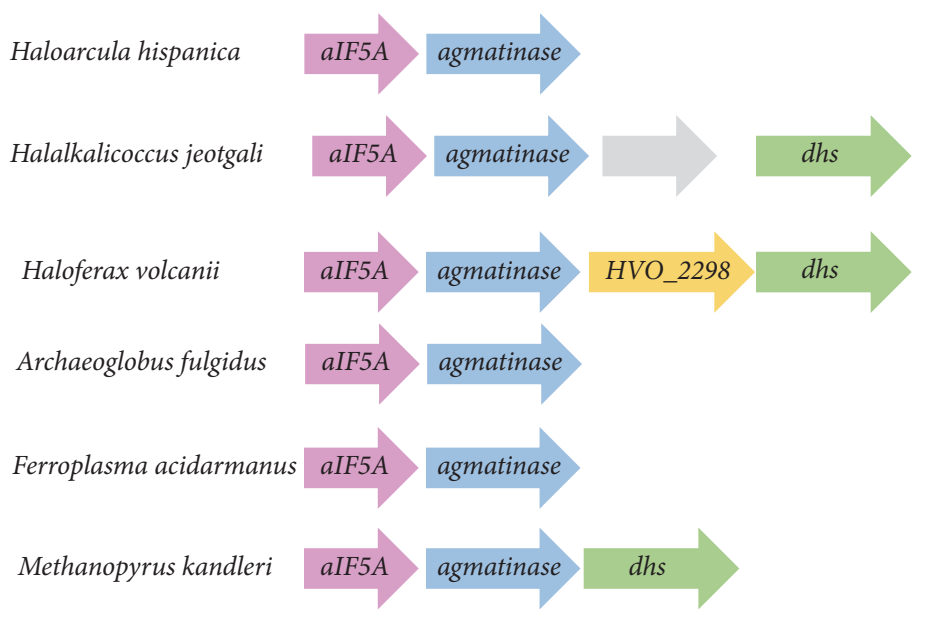

Figure 2: HVO_2299 of Hfx. volcanii clusters with aIF5A. Physical gene clustering links genes encoding agmatinase, DHS, and aIF5A in Euryarchaeota. In pink, aIF5A (HVO_2300 in Hfx. volcanii); in blue, agmatinase (HVO_2299 in Hfx. volcanii); in yellow, gene encoding HVO_2298; DHS (HVO_2297 in Hfx. volcanii). Arrows represent the genes. Physical clustering was analyzed on the STRING database.

by [37] are that the Hfx. volcanii DHS (i) transfers directly putrescine (Figure 1(b)) or the aminobutyl group of agmatine to aIF5A (Figure 1(c)) and (ii) transfers agmatine to aIF5A, with the agmatinase acting on the modified protein substrate to produce the deoxyhypusinylated derivative (Figure 1(d)).

\subsection{Hfx. volcanii aIF5A Is Expressed Throughout the Growth} Curve and Deoxyhypusinylated In Vivo. The Hfx. volcanii gene predicted to encode aIF5a (HVO_2300) is essential [12], but little else is known about this gene/protein in this organism. To obtain a better understanding of aIF5A in Archaea and specifically in halophiles, aIF5A levels at different growth phases were monitored by Western blot using $H f x$. volcanii anti-aIF5A antibodies (TIF5A2 and TIF5A3) (Figures 3(a) and $3(\mathrm{~b})$ ). Both antibodies independently detected aIF5A at around $20 \mathrm{kDa}$ for an expected theoretical mass of $14.2 \mathrm{kDa}$. The observed size difference is most likely due to the known slow mobility of halophilic proteins on SDS-PAGE [71-73]. Similar levels of the aIF5A protein were detected for up to 25 hours of growth, after which the levels of aIF5A diminished (Figure 3(b)). Few studies have the regulation of eIF5A in Eukaryotes but it has been suggested that eIF5A levels are regulated in a proteasome-dependent manner $[74,75]$. The effects of different stresses (proteasome inhibitor, cold shock, and oxidative stress) on the level of aIF5A were therefore monitored (as described in Section 2). We did not notice any effect of the proteasome inhibitor (Fig. S2A) or cold shock on the level of aIF5A (data not shown). Interestingly, the presence of $0.78 \%(\mathrm{w} / \mathrm{v}) \mathrm{H}_{2} \mathrm{O}_{2}$ led to a change in the cell lysate protein pattern (Figure 3(c)). For the same quantities of cells (measured by OD), an additional higher molecular weight band (around $85 \mathrm{kDa}$ ) was observed (Figure 3(c)). The band at $85 \mathrm{kDa}$ could be the result of protein modifications or aggregation due to the stress. Additional work is needed to understand the mechanisms that regulate aIF5A in Archaea and more generally the effects of oxidative stress on the $H f x$. volcanii proteome.
In order to determine whether the Hfx. volcanii aIF5A is modified by hypusine or deoxyhypusine, the protein was purified to an apparent homogeneity as an $18 \mathrm{kDa}$ protein (Fig. S2B) from strain VDC2577 (TIF5A-C-term His integrant) via affinity chromatography. We were able to detect the deoxyhypusine/hypusine modification of the purified aIF5A using the IU-88 antibody [55] (kind gift of Dr. Mirmira) (Fig. S2B). The IU-88 antibody failed to detect the modified aIF5A on cell lysates throughout the different growth phases (data not shown). As this antibody recognizes both the deoxyhypusine and hypusine forms of eIF5A [55], the $18 \mathrm{kDa}$ protein band was cut out from the SDS-PAGE, digested with LysC, and analyzed by mass spectrometry (Figure $3(\mathrm{~d})$ ). This analysis confirmed that the purified protein is aIF5A-modified with deoxyhypusine at the conserved lysine (position 36) (Figure 3(d)). Furthermore, when comparing the intensities for unmodified, hypusinylated, and deoxyhypusinylated PGKHGSAK peptides, approximately $99 \%$ of the aIF5A protein is deoxyhypusinylated. Our results confirm the previous observation by amino acid analysis of the presence of deoxyhypusine in halophiles [32] and show for the first time by MS that $H f x$. volcanii aIF5A is deoxyhypusinylated. Our data suggest that $H f x$. volcanii aIF5A is exclusively deoxyhypusinylated in the cell, as no pool of unmodified aIF5A was detected in the purified fraction and correlates with the absence of $\mathrm{DOOH}$ homologs in this organism. Indeed, in Eukaryotes hypusination of eIF5A appears to be constitutive as hypusination occurs shortly after protein synthesis with no evidence of modification turn-over [30,31, $76,77]$. We propose that the deoxyhypusinylated aIF5A is the active form in Hfx. volcanii, as it has been shown in $S$. cerevisiae that the partially modified deoxyhypusine eIF5A was functional $[1,3]$.

3.3. Intracellular Polyamines Composition of Hfx. volcanii. Previous polyamine composition analysis studies of halophilic Archaea were performed in various media types 


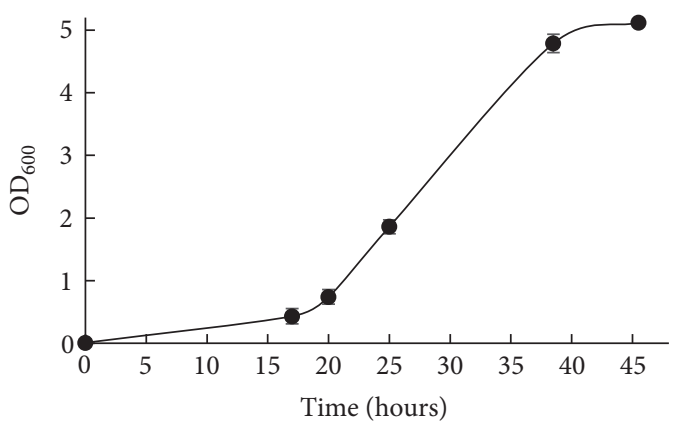

(a)

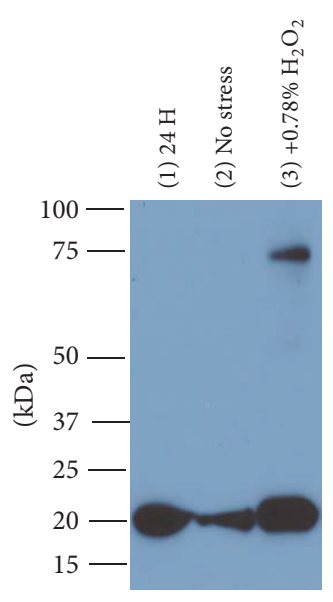

IB: $\alpha$-TIF5A2

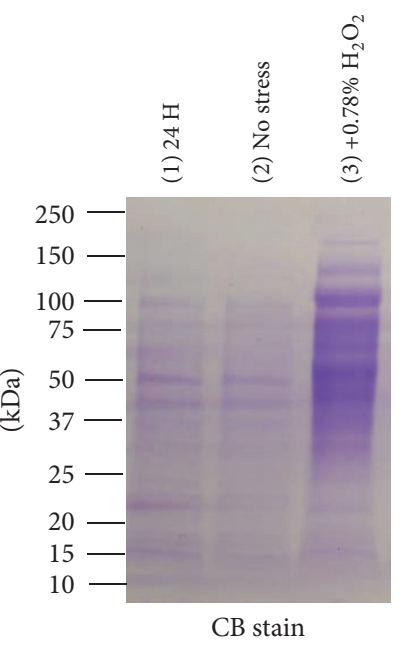

(c)

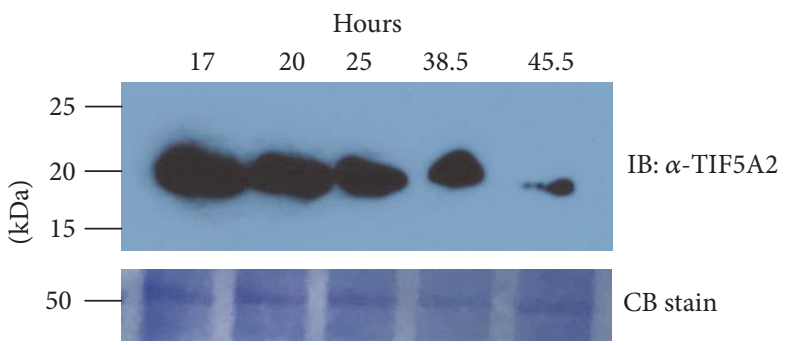

(b)

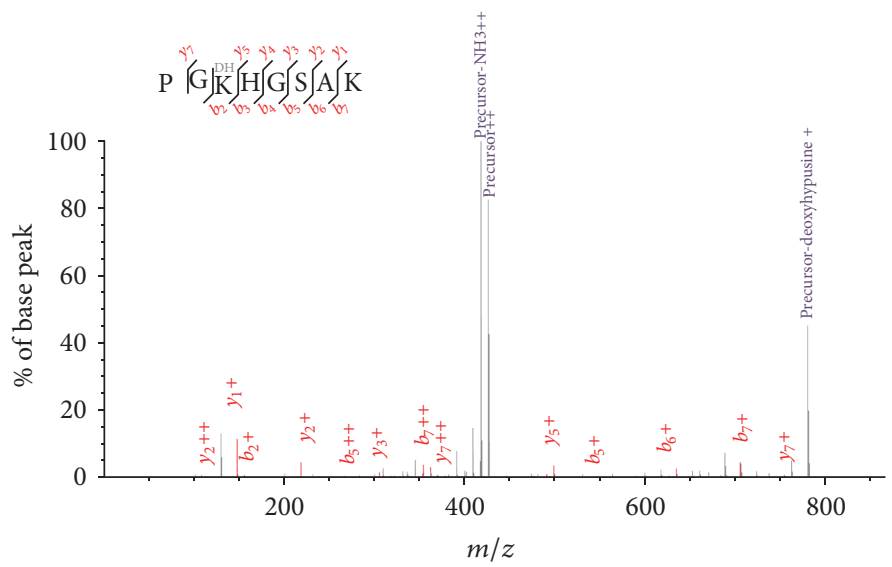

(d)

FIGURE 3: aIF5A produced in Hfx. volcanii is deoxyhypusinylated and sensitive to oxidative stress. (a) $H f x$. volcanii $\mathrm{H} 26$ was grown at $42^{\circ} \mathrm{C}$ in ATCC974 (shaking at $200 \mathrm{rpm}$ ). $2 \mathrm{~mL}$ of samples at $\mathrm{OD}_{600}=0.043$ was harvested along the growth curve. (b) $\mathrm{H} 26$ cells pellets ( 2 mL at $\mathrm{OD}_{600}$ $=0.043$ of the culture) were resuspended in SDS-PAGE loading buffer and boiled for $15 \mathrm{~min}$. Equivalent protein loading was based on $\mathrm{OD}_{600}$ of cell culture $\left(0.086 \mathrm{OD}_{600}\right.$ units per lane), as demonstrated by staining with Coomassie Brilliant Blue R-250 (CB stain, with representative $55 \mathrm{kDa}$ protein band of Hfx. volcanii presented). Proteins were separated via $4-15 \%$ reducing SDS-PAGE. aIF5A was detected by $\alpha$-aIF5A (anti-TIF5A2) immunoblot (IB). The experiments were performed with three biological replicates and the detection by anti-TIF5A2 or antiTIF5A3. The molecular mass indicated is in $\mathrm{kDa}$. (c) Effect of oxidative stress on aIF5A level. The cells were grown for 24 hours and then treated or not treated with $0.78 \% \mathrm{H}_{2} \mathrm{O}_{2}$. Equivalent protein loading was based on $\mathrm{OD}_{600}$ of cell culture $\left(0.086 \mathrm{OD}_{600}\right.$ units per lane). Lane 1, cells collected at 24 hours; lane 2, cells collected at +4 hours after no stress (control experiment); lane 3, cells collected at +4 hours after $0.78 \% \mathrm{H}_{2} \mathrm{O}_{2}$ treatment. Proteins were separated by $4-15 \%$ reducing SDS-PAGE. aIF5A was detected via $\alpha$-aIF5A (anti-TIF5A2) immunoblot (IB). The molecular mass indicated is in $\mathrm{kDa}$. (d) Identification of the deoxyhypusine modification by LC-MS/MS analysis. The purified aIF5A His-C-term was loaded on a SDS-PAGE 12\%. The proteins were detected by staining with Coomassie Blue (Fig S2B), and the protein band was cut and analyzed by LC-MS/MS analysis. Fragmentation spectrum for deoxyhypusinylated peptide PGKHGSAK is shown; xiSPEC (http://spectrumviewer.org/) was used for annotation.

depending on the study and specific organism investigated, making it difficult to compare results. Indeed, when cells were grown in rich medium contamination with salvaged polyamines can occur [40] as summarized in Table S1. To obtain more information, the intracellular polyamine composition in $H f x$. volcanii $\mathrm{H} 26$ was analyzed by HPLC. Intracellular polyamines were extracted at different growth stages ( 20 hours, 35 hours, and 40 hours) of cells grown in minimal medium (Hv_min). Two major peaks were detected at the position of agmatine and cadaverine (Figure 4). In these conditions, no changes in polyamines composition during growth were observed (Figure 4 and Fig. S3). Agmatine was found to be the more abundant polyamine at all growth stages (Figure 4(b) and Fig. S3). This result confirms previous studies assigning agmatine as the major polyamine in halophilic archaea and in $H f x$. volcanii (Table S1) [41, 78-80]. Hamana et al. reported the presence of a small amount of putrescine when $H f x$. volcanii was grown in rich medium [41] (Table S1) (medium NCIMB 2012 at $30^{\circ} \mathrm{C}$ ). This result was not reproduced in minimal medium. The presence of cadaverine was not predicted from the initial metabolic reconstruction (Figure 1(a)). It has been shown in some Bacteria that the L-2,4-diaminobutyrate decarboxylase, involved in siderophore synthesis, can also function as a lysine decarboxylase [70]. Our results suggest that this could also be the case in $H f x$. volcanii as the gene HVO_B0045 is 


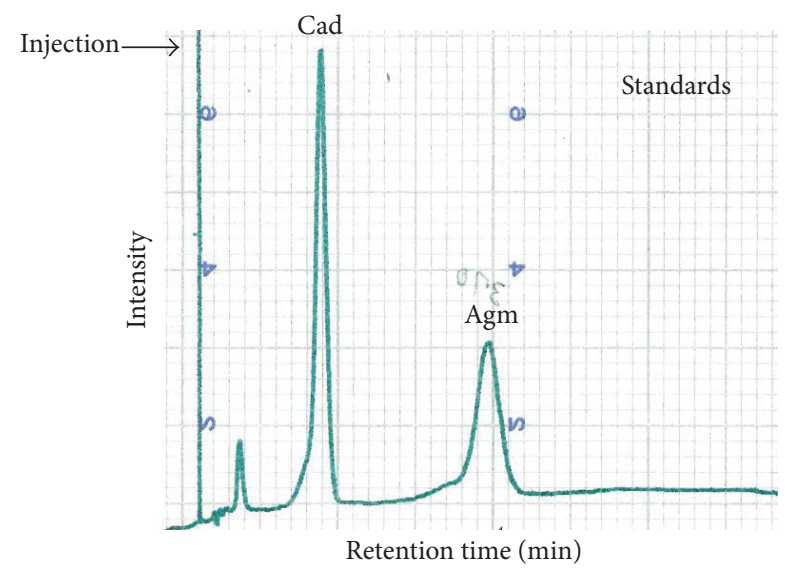

(a)

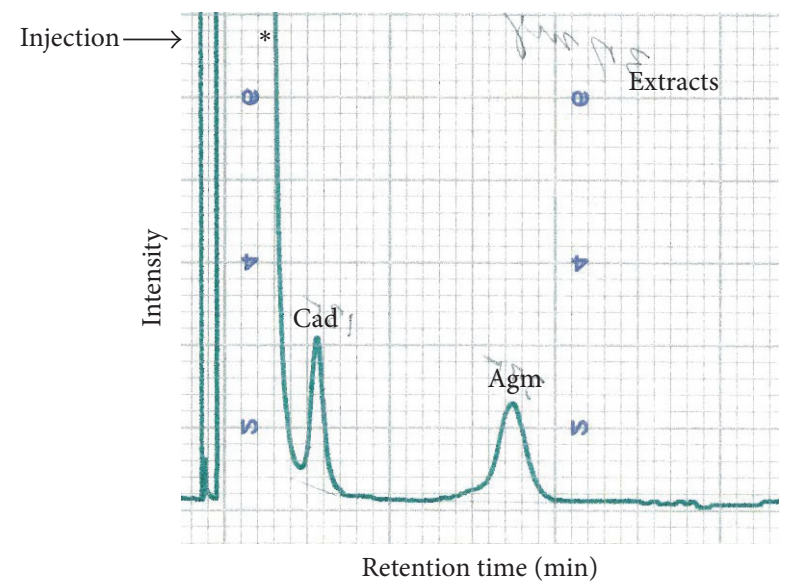

(b)

FIGURE 4: Intracellular polyamines analyses in $H f x$. volcanii $\mathrm{H} 26$. $\mathrm{H} 26$ was grown at $42^{\circ} \mathrm{C}$ in $\mathrm{Hv} \_$min medium. Intracellular polyamines from $H f x$. volcanii $\mathrm{H} 26$ were extracted after 20 hours of growth. (a), peak standards; (b), samples after 20 hours of growth. Thirty-seven mg of extracts was injected. The ratio agmatine/cadaverine is $6.96 \pm 3.28$. The injection is indicated by the arrow; * unexpected noise derived from buffer.

predicted to encode L-2,4-diaminobutyrate decarboxylase. Cadaverine had previously been reported in a few halophilic Archaea (Table S1) and it might have a role in resistance of these organisms to high salt since this metabolite has been linked to $\mathrm{pH}$ and salt resistance [81, 82]. The absence of spermidine is also consistent with previous work (Table S1) and with the fact that no dcSAM synthesis enzyme is encoded by $H f x$. volcanii (Figure 1(a)). These results raise the question of the role of the SpeE homologs (HVO_0255 and HVO_B0357) in this halophile.

3.4. Arginine Decarboxylase Is Essential for the Growth of Hfx. volcanii. To confirm that HVO 1958 encodes an arginine decarboxylase, the gene was deleted (Fig. S4A-B) and the growth of the deletion strain was compared to its parent $(\mathrm{H} 26)$ at $42^{\circ} \mathrm{C}$ in the absence (Figure $5(\mathrm{a})$ ) or presence of agmatine (Figures 5(b) and 5(c)). The $\triangle H V O \_1958$ strain is

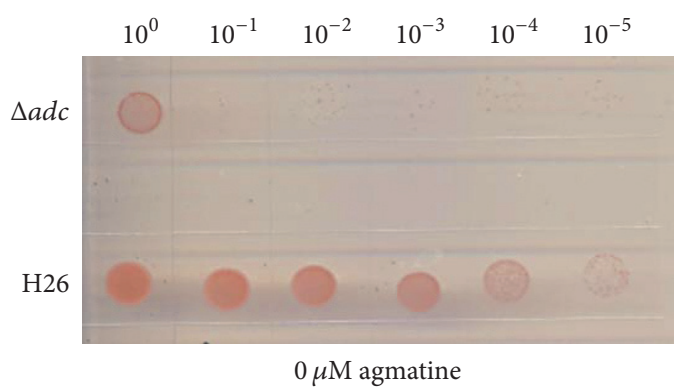

(a)

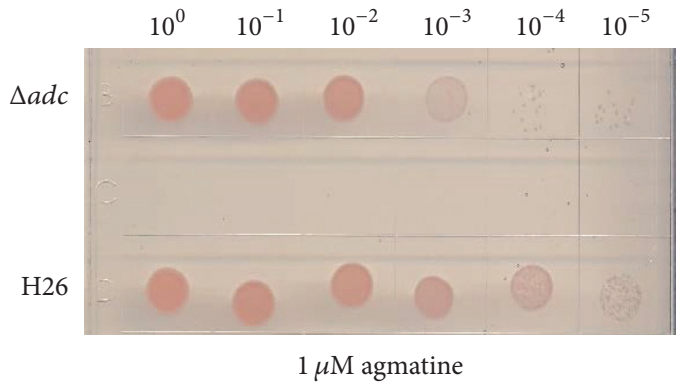

(b)

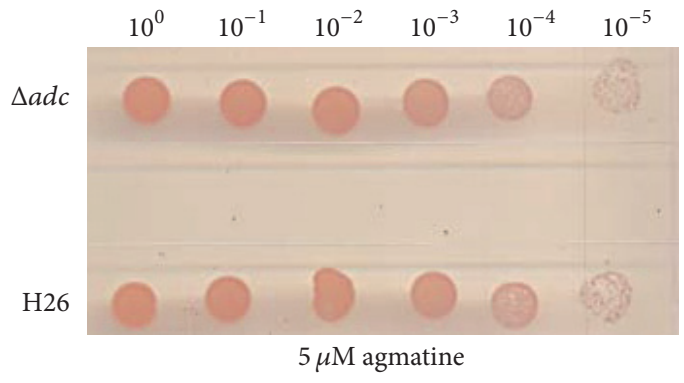

(c)

FIgUre 5: Agmatine is essential for the growth of the $H f x$. volcanii $\Delta a d c$ strain. $H f x$. volcanii H26 (WT, parent) and $\Delta a d c$ (HVO_1958) were diluted to an $\mathrm{OD}_{600}$ of 1 and then spot-plated $(15 \mu \mathrm{L})$ on solid agar Hv_min medium in serial dilutions as indicated: (a) in absence of agmatine; (b) in presence of $1 \mu \mathrm{M}$ agmatine; (c) in presence of $5 \mu \mathrm{M}$ agmatine. Each experiment was performed with two biological replicates and three technical replicates (for description of biological versus technical replicates).

auxotrophic for agmatine and requires $5 \mu \mathrm{M}$ agmatine for full growth (Figure 5(c)) and was therefore renamed $\Delta a d c$. Partial growth was observed at lower agmatine concentrations (Figure 5(b)) but no growth was observed for $<1 \mu \mathrm{M}$ agmatine (data not shown). As already seen with the T. kodakarensis $\Delta a d c$ strain [65], growth of the Hfx. volcanii $\Delta a d c$ mutant could only be rescued by agmatine and not by any of the other tested polyamines such as putrescine, spermidine, cadaverine, or ornithine (Fig. S5). Moreover, the addition of polyamines in the media had no effect on the growth of the parent strain $H f x$. volcanii H26 (Fig. S5). These genetic experiments support the model in which the HVO_1958 encoded ADC is the first enzyme of polyamine synthesis in $H f x$. volcanii producing the essential intermediate agmatine (Figure 1(a)). Our genetic studies corroborate our polyamines 
analyses since deleting the predicted arginine decarboxylase gene (HVO_1958) led to an agmatine auxotroph strain. The agmatine produced by $H f x$. volcanii ADC is certainly a precursor to the formation of the essential agmatidine tRNA modification catalyzed by TiaS (Figure 1(a)), but it could also be required for the formation of the essential deoxyhypusine modification as a direct substrate of DHS (Figures 1(c) and $1(d)$ ) or as the precursor of the final polyamine substrate for the DHS reaction (Figures $1(\mathrm{a})$ and $1(\mathrm{~b})$ ).

3.5. HVO_2299, Gene Encoding an Agmatinase-Like Protein, Is Essential. The metabolic reconstruction described above suggests a role of $\mathrm{HVO}_{2} 299$ as an agmatinase involved in forming putrescine from agmatine (Figure 1(a)). However, neither putrescine nor the downstream product spermidine was detected in our polyamine analysis of $H f x$. volcanii (Figure 4). To gain further insight into the role of agmatinase, the gene neighborhood of the HVO_2299 was explored (Figure 2). Our analysis uncovered strong physical clustering associations between the aIF5A and agmatinase encoding genes, with $39 \%$ of the archaeal genomes present in the STRING database (out of the 130 archaeal genomes) showing this association (Figure 2). These clusters were almost exclusively observed in Euryarchaeota and were present in $\sim 62 \%$ of the Euryarchaeota and in the unclassified archaea halophilic archaeon DL31. Interestingly, the association aIF5A/agmatinase was not found in the Crenarchaeota phylum, where $a I F 5 A$ was found associated with genes encoding DNA topoisomerase IV subunit B, DNA topoisomerase VI subunit A, and DHS (data not shown). Physical clustering evidence strongly pointed to a role of HVO_2299 in aIF5a modification. This agmatinase-like protein could be involved in the formation of the intermediate putrescine (Figure 1(a)), even if it has not been detected in our analyses or could directly hydrolyze a modified aIF5a precursor to form the final deoxyhypusine modification (Figure 1(d)).

To investigate if HVO_2299 is essential for Hfx. volcanii cell viability, we attempted to delete the gene from its chromosomal locus. Around 220 candidate colonies were screened but no deletion mutant was obtained suggesting the essentiality of this gene. The deletion of the gene failed even in the presence of $1 \mathrm{mM}$ putrescine. We then proceeded to clone the HVO_2299 into pPT002 plasmid, placing the gene under the tryptophanase promoter $[49,83]$. The plasmid was transformed into the "pop-in strain." In this background, it was possible to delete the chromosomal copy of the HVO_2299 (Fig. S4 C-D), again strongly suggesting essentiality of the gene. However, growth was still observed in the absence of tryptophan, certainly caused by the known the leakiness of the $\mathrm{P}_{\mathrm{TNA}}$ promoter in multicopy plasmids [49].

The fact that the HVO_2299 gene encoding an agmatinase-like protein is essential even in the presence of putrescine, as well as the absence of any detected intracellular putrescine, suggests that this enzyme is not involved in the formation of putrescine from agmatine in $H f x$. volcanii. One, however, cannot rule out the possibility that putrescine is not imported in this organism and has to be produced de novo and immediately used to modify aIF5a by DHS (Figure 1(b)), reducing its accumulation to below detectable limits. This is unlikely as all the genes encoding spermidine/putrescine ABC transporter [PotA1 (HVO_A293) and PotA2 (HVO_A293), PotB (HVO_A300), PotC (HVO_A297) and PotD (HVO_A299)] are found in the Hfx. volcanii genome on the $\mathrm{pHV} 4$ plasmid in a physical cluster (data not shown). If putrescine is transported in the cell, then the essentiality of HVO_2299 would favor a model where the agmatinase protein might be hydrolyzing the agmatine moiety after its transfer to aIF5A (Figure 1(d)). Further efforts are required to undercover the function of the agmatinaselike protein in Hfx. volcanii.

3.6. Deoxyhypusine Synthase Activities in Euryarchaeota. $N^{1}$ Guanyl-1,7-diaminoheptane (GC7) is a very efficient inhibitor of DHS in eukaryotes. This homolog of spermidine inhibits the first step in the hypusination pathway by binding to DHS [28, 29]. Cultures of Sulfolobus acidocaldarius DSM 639, Sulfolobus solfataricus DSM, Halobacterium halobium DSM 670, and Haloferax mediterranei DSM were shown to be sensitive to GC7 [33]. To determine the effect of GC7 on $H f x$. volcanii culture, $\mathrm{H} 26$ was grown in the absence or presence of $1 \mathrm{mM}$ GC7 at $42^{\circ} \mathrm{C}$ on Hv_min agar. As shown in Figure 6(a), we did not observe any effect of GC7 on the growth of H26 even if it should be transported by the predicted spermidine/putrescine ABC transporter present in $H f x$. volcanii. The same results were observed in liquid cultures, although the compound did affect growth of Saccharomyces cerevisiae cultures as expected (data not shown).

To determine whether the DHS of $H f x$. volcanii transfers the 4-aminobutyl moiety from spermidine to the Hfx. volcanii aIF5A lysine side chain, the protein was expressed from $H f x$. volcanii (LSP5021). The protein T7-His-DHS was purified as a tetramer with an estimated molecular weight of around $148 \mathrm{kDa}$ (Fig S6). The oligomerization state of the purified DHS is in agreement with the crystal structure of the Human and other characterized DHS enzymes [84-86]. The substrate of the reaction, Hfx. volcanii aIF5A-C-term-His, was overexpressed in E. coli and purified in two steps. The purified Hfx. volcanii T7-His-DHS did not show any activity under varying aIF5A concentration and substrate concentration (spermidine, agmatine, cadaverine, and putrescine) (data not shown). In an effort to determine if the lack of activity of the DHS was due to the presence of the T7-His tag, the protein was expressed without tag and the DHS activities were tested in the Hfx. volcanii cell lysate. No DHS activity was detected in the cell lysate (Fig. S7). The lack of activity was not due to a defect of the Hfx. volcanii aIF5A-C-term-His substrate, since the $S$. cerevisiae DHS catalyzed the transfer of 4-aminobutyl moiety from spermidine to the Hfx. volcanii aIF5a-C-term-His (Fig. S7, lane 11). DHS sequences from Archaea that are sensitive to GC7 [34] (Fig. S8, group A) and halophilic Archaea that harbor the polyamine cadaverine like Hfx. volcanii (Fig. S8, group B) were aligned and the active site and spermidine substrate binding residues mapped. If the active site K329 (Human, P49366) is strictly conserved from Human to all archaeal DHS proteins, the spermidine binding sites residues are not (Fig. S8). One of the spermidine binding residues $(\mathrm{H} 288)$ is strictly conserved in Eukarya and in the 


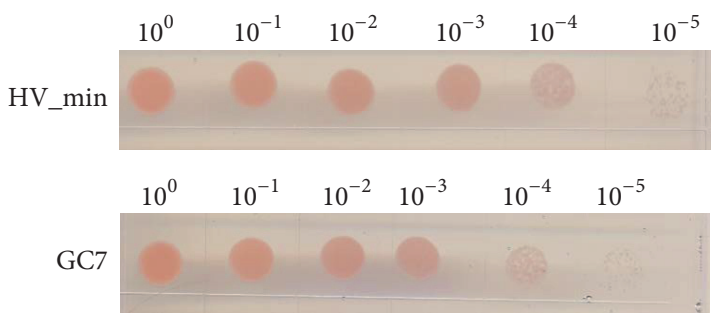

(a)

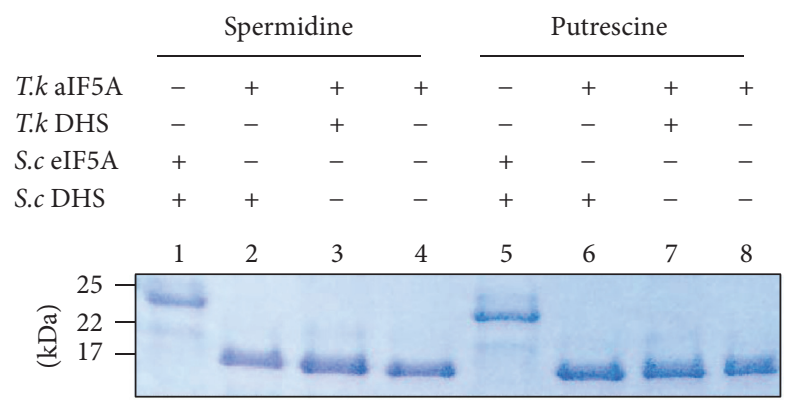

(i)

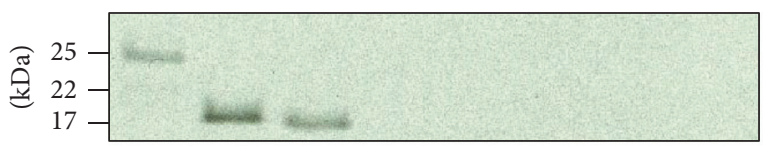

(ii)

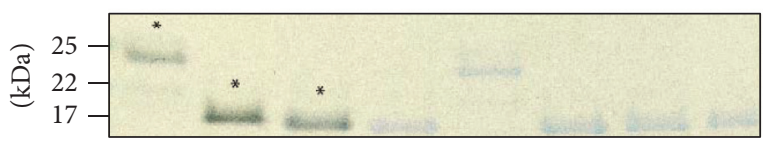

(iii)

(b)

FIGURE 6: Hfx. volcanii is insensitive to GC7 and spermidine is the substrate of T. kodakarensis DHS. (a) Effect of GC7 on the growth of $\mathrm{H} 26$. Hfx. volcanii $\mathrm{H} 26$ (WT, parent) was diluted to $\mathrm{OD}_{600}$ of 1 and then spot-plated $(15 \mu \mathrm{L})$ on solid agar Hv_min medium in serial dilutions as indicated in absence or in presence of $1 \mathrm{mM}$ GC7. Each experiment was performed with two biological replicates and three technical replicates. (b) Detection of T. kodakarensis aIF5A (lanes 2, $3,4,6,7$, and 8 ) and S. cerevisiae eIF5A (lanes 1 and 5) modification using $\left[{ }^{14} \mathrm{C}\right]$ spermidine or $\left[{ }^{3} \mathrm{H}\right]$ putrescine as substrates in presence of T. kodakarensis DHS (lanes 3 and 7) or S. cerevisiae DHS (lanes 1,2 , and 5). The in vitro assay was resolved on a $16.5 \%$ tricine polyacrylamide gel. The dried gels were exposed to autoradiography films to visualize possible modifications. The assembly of each reaction is depicted above. (i), Coomassie Blue staining; (ii), exposed autoradiography film; (iii), overlay of the Coomassie Blue stained gel and the exposed film; $*$ indicates the presence of the radioactivity; molecular mass markers are indicated in $\mathrm{kDa}$; T.k, Thermococcus kodakarensis; S.c, Saccharomyces cerevisiae.

group A Archaea (sensitive to GC7) but this residue is not conserved in the group B Archaea (that harbor cadaverine). Those differences could explain why GC7 and spermidine do not bind Hfx. volcanii DHS. This study opens the question of DHS in halophile organisms.
As a further control, the in vitro DHS activity of another member of the Euryarchaeota was explored. Recombinant DHS from the thermophile T. kodakarensis and its substrate aIF5A were purified and the activity was tested in presence of radioactive spermidine or putrescine. Similar to the eukaryotic enzyme (Figure 6(b), lane 1), the DHS of T. kodakarensis transfers 4-aminobutyl from spermidine to $T$. kodakarensis aIF5A in vitro (Figure 6(b), lane 3). No transfer was observed in absence of the enzyme (Figure 6(b), lane 4) or in presence of putrescine (Figure 6(b), lane 7). The modified T. kodakarensis aIF5A was analyzed by mass spectrometry demonstrating the presence of the deoxyhypusine on the conserved lysine K42 (Fig. S9).

The absence of any effect of the GC7 on $H f x$. volcanii growth as well as the inability to observe transfer of 4aminobutyl suggests that spermidine is not the substrate of the Hfx. volcanii DHS, corroborating the metabolic reconstruction and the fact that no intracellular spermidine was detected. We cannot rule out the possibility that GC7 was not imported into the cells, despite the presence of the spermidine/putrescine $\mathrm{ABC}$ transporter genes and that the Hfx. volcanii DHS was purified in an inactive form. Unfortunately, our attempts to test the different models (Figures 1(b), 1(c), and $1(\mathrm{~d})$ ) by testing the activity of the Hfx. volcanii DHS protein in vitro remained unsuccessful. We were able to purify an active aIF5A that could be deoxyhypusinylated with the $S$. cerevisiae DHS using spermidine as aminobutyl donor, but all attempts with $H f x$. volcanii DHS failed using spermidine, putrescine, or agmatine as donors. Nevertheless, we could show for the first time the in vitro activity of the T. kodakarensis DHS with the transfer of 4-aminobutyl from spermidine to aIF5A, as in Eukaryotes.

\section{Conclusion}

We have demonstrated that Hfx. volcanii aIF5A is deoxyhypusinylated. The absence of spermidine in $H f x$. volcanii was confirmed, and the major polyamines in this halophile were found to be agmatine and cadaverine. We propose that deoxyhypusine synthesis in Hfx. volcanii differs from the canonical eukaryotic pathway. Based on our observation that (i) GC7, the spermidine analog that inhibits yeast DHS, does not inhibit Hfx. volcanii growth, (ii) the agmatinase-like gene that clusters with the dhs gene is essential for the growth of $H f x$. volcanii even in the presence of putrescine, and (iii) there is no activity of the Hfx. volcanii DHS with spermidine, we favor the model in Figure 1(d), where DHS transfers agmatine to the aIF5A lysine and the agmatinase enzyme is required to produce deoxyhypusine.

\section{Nonstandard Abbreviations}

ADC: $\quad$ Arginine decarboxylase

AdoMet DC: AdoMet decarboxylase

Amp: Ampicillin

AUH: Agmatinase/agmatine ureohydrolase

dcAdoMet: Decarboxylated adenosylmethionine

DHS: Deoxyhypusine synthase

DOHH: Deoxyhypusine hydroxylase 
eIF5A: Eukaryotic initiation factor 5A

aIF5A: Archaeal initiation factor 5A

GC7: $\quad N^{1}$-Guanyl-diaminoheptane

HTP: Hydroxyapatite column

LC: Liquid chromatography

TCA: Trichloroacetic acid

IF5a: Translation initiation factor 5A.

\section{Disclosure}

Ian K. Blaby's current address is Biology Department, Brookhaven National Laboratory, Building 463, 50 Bell Avenue, Upton, NY 11973, USA. Agata L. Starosta's current address is Centre for Bacterial Cell Biology, Institute for Cell and Molecular Biosciences, University of Newcastle, Newcastle upon Tyne, United Kingdom.

\section{Competing Interests}

The authors have not conflict of interests to declare.

\section{Acknowledgments}

The authors thank S. Sanker at the UF ICBR genomics core for Sanger DNA sequencing. They gratefully acknowledge Christopher Gardner for the FPLC system. They are grateful to Dr. Mirmira for providing them with the IU-88 antibody. They thank Dr. Thiaville for constructing the pPT002 derivative of pJAM202, a kind gift of Dr. Maupin-Furlow. This work was funded by NIH R01 GM7064 (to V. de Crécy-Lagard) and by the Deutsche Forschungsgemeinschaft WI3285/4-1 (to D. N. Wilson).

\section{References}

[1] T. E. Dever, E. Gutierrez, and B.-S. Shin, "The hypusinecontaining translation factor eIF5A," Critical Reviews in Biochemistry and Molecular Biology, vol. 49, no. 5, pp. 413-425, 2014.

[2] M. Caraglia, M. H. Park, E. C. Wolff, M. Marra, and A. Abbruzzese, "EIF5A isoforms and cancer: two brothers for two functions?" Amino Acids, vol. 44, no. 1, pp. 103-109, 2013.

[3] M. B. Mathews and J. W. B. Hershey, "The translation factor eIF5A and human cancer," Biochimica et Biophysica Acta - Gene Regulatory Mechanisms, vol. 1849, no. 7, pp. 836-844, 2015.

[4] L. K. Doerfel, I. Wohlgemuth, C. Kothe, F. Peske, H. Urlaub, and M. V. Rodnina, "EF-P is essential for rapid synthesis of proteins containing consecutive proline residues," Science, vol. 339, no. 6115, pp. 85-88, 2013.

[5] S. Ude, J. Lassak, A. L. Starosta, T. Kraxenberger, D. N. Wilson, and K. Jung, "Translation elongation factor EF-P alleviates ribosome stalling at polyproline stretches," Science, vol. 339, no. 6115, pp. 82-85, 2013.

[6] E. Gutierrez, B.-S. Shin, C. J. Woolstenhulme et al., "eif5A promotes translation of polyproline motifs," Molecular Cell, vol. 51, no. 1, pp. 35-45, 2013.

[7] L. Peil, A. L. Starosta, J. Lassak et al., "Distinct XPPX sequence motifs induce ribosome stalling, which is rescued by the translation elongation factor EF-P," Proceedings of the National
Academy of Sciences of the United States of America, vol. 110, no. 38, pp. 15265-15270, 2013.

[8] S. Elgamal, A. Katz, S. J. Hersch et al., "EF-P dependent pauses integrate proximal and distal signals during translation," PLoS Genetics, vol. 10, no. 8, Article ID e1004553, 2014.

[9] A. L. Starosta, J. Lassak, L. Peil et al., "Translational stalling at polyproline stretches is modulated by the sequence context upstream of the stall site," Nucleic Acids Research, vol. 42, no. 16, pp. 10711-10719, 2014.

[10] C. J. Woolstenhulme, N. R. Guydosh, R. Green, and A. R. Buskirk, "High-precision analysis of translational pausing by ribosome profiling in bacteria lacking EFP," Cell Reports, vol. 11, no. 1, pp. 13-21, 2015.

[11] M. H. Park, K. Nishimura, C. F. Zanelli, and S. R. Valentini, "Functional significance of eIF5A and its hypusine modification in eukaryotes," Amino Acids, vol. 38, no. 2, pp. 491-500, 2010.

[12] K. Gäbel, J. Schmitt, S. Schulz, D. J. Näther, and J. Soppa, "A comprehensive analysis of the importance of translation initiation factors for haloferax volcanii applying deletion and conditional depletion mutants," PLoS ONE, vol. 8, no. 11, Article ID e77188, 2013.

[13] W.-T. Peng, L. M. Banta, T. C. Charles, and E. W. Nester, "The chvH locus of Agrobacterium encodes a homologue of an elongation factor involved in protein synthesis," Journal of Bacteriology, vol. 183, no. 1, pp. 36-45, 2001.

[14] E. De Crécy, D. Metzgar, C. Allen et al., "Development of a novel continuous culture device for experimental evolution of bacterial populations," Applied Microbiology and Biotechnology, vol. 77, no. 2, pp. 489-496, 2007.

[15] C. J. Balibar, D. Iwanowicz, and C. R. Dean, "Elongation factor P is dispensable in Escherichia coli and Pseudomonas aeruginosa," Current Microbiology, vol. 67, no. 3, pp. 293-299, 2013.

[16] T. Yanagisawa, H. Takahashi, T. Suzuki, A. Masuda, N. Dohmae, and S. Yokoyama, "Neisseria meningitidis translation elongation factor $\mathrm{P}$ and its active-site arginine residue are essential for cell viability," PLoS ONE, vol. 11, no. 2, Article ID e0147907, 2016.

[17] W. W. Navarre, S. B. Zou, H. Roy et al., "PoxA, YjeK, and elongation factor $\mathrm{P}$ coordinately modulate virulence and drug resistance in Salmonella enterica," Molecular Cell, vol. 39, no. 2, pp. 209-221, 2010.

[18] T. Yanagisawa, T. Sumida, R. Ishii, C. Takemoto, and S. Yokoyama, "A paralog of lysyl-tRNA synthetase aminoacylates a conserved lysine residue in translation elongation factor P," Nature Structural and Molecular Biology, vol. 17, no. 9, pp. 1136$1143,2010$.

[19] H. Roy, S. B. Zou, T. J. Bullwinkle et al., "The tRNA synthetase paralog PoxA modifies elongation factor-P with $(R)-\beta$-lysine," Nature Chemical Biology, vol. 7, no. 10, pp. 667-669, 2011.

[20] L. Peil, A. L. Starosta, K. Virumäe et al., "Lys34 of translation elongation factor EF-P is hydroxylated by YfcM," Nature Chemical Biology, vol. 8, no. 8, pp. 695-697, 2012.

[21] T. J. Bullwinkle, S. B. Zou, A. Rajkovic et al., “(R)- $\beta$-lysinemodified elongation factor $\mathrm{p}$ functions in translation elongation," Journal of Biological Chemistry, vol. 288, no. 6, pp. 44164423, 2013.

[22] J. Lassak, E. C. Keilhauer, M. Fürst et al., "Arginine-rhamnosylation as new strategy to activate translation elongation factor P," Nature Chemical Biology, vol. 11, no. 4, pp. 266-270, 2015.

[23] A. Rajkovic, S. Erickson, A. Witzky et al., "Cyclic rhamnosylated elongation factor $\mathrm{P}$ establishes antibiotic resistance in Pseudomonas aeruginosa," mBio, vol. 6, no. 3, Article ID e00823, 2015. 
[24] K. Y. Chen and A. Y.-C. Liu, "Biochemistry and function of hypusine formation on eukaryotic initiation factor 5A," Biological Signals, vol. 6, no. 3, pp. 105-109, 1997.

[25] M. H. Park, "The post-translational synthesis of a polyaminederived amino acid, hypusine, in the eukaryotic translation initiation factor 5A (eIF5A)," Journal of Biochemistry, vol. 139, no. 2, pp. 161-169, 2006.

[26] E. C. Wolff, K. R. Kang, Y. S. Kim, and M. H. Park, "Posttranslational synthesis of hypusine: evolutionary progression and specificity of the hypusine modification," Amino Acids, vol. 33, no. 2, pp. 341-350, 2007.

[27] C. F. Zanelli and S. R. Valentini, "Is there a role for eIF5A in translation?” Amino Acids, vol. 33, no. 2, pp. 351-358, 2007.

[28] J. Jakus, E. C. Wolff, M. H. Park, and J. E. Folk, "Features of the spermidine-binding site of deoxyhypusine synthase as derived from inhibition studies. effective inhibition by bis- and monoguanylated diamines and polyamines," Journal of Biological Chemistry, vol. 268, no. 18, pp. 13151-13159, 1993.

[29] Young Bok Lee, Myung Hee Park, and J. E. Folk, "Diamine and triamine analogs and derivatives as inhibitors of deoxyhypusine synthase: synthesis and biological activity," Journal of Medicinal Chemistry, vol. 38, no. 16, pp. 3053-3061, 1995.

[30] M. H. Park, "Regulation of biosynthesis of hypusine in Chinese hamster ovary cells. Evidence for eIF-4D precursor polypeptides," The Journal of Biological Chemistry, vol. 262, no. 26, pp. 12730-12734, 1987.

[31] R. J. Murphey and E. W. Gerner, "Hypusine formation in protein by a two-step process in cell lysates," Journal of Biological Chemistry, vol. 262, no. 31, pp. 15033-15036, 1987.

[32] D. Bartig, H. Schumann, and F. Klink, “The unique posttranslational modification leading to deoxyhypusine or hypusine is a general feature of the archaebacterial kingdom," Systematic and Applied Microbiology, vol. 13, no. 2, pp. 112-116, 1990.

[33] B. P. M. Jansson, L. Malandrin, and H. E. Johansson, "Cell cycle arrest in archaea by the hypusination inhibitor $N^{1}$-guanyl-1,7diaminoheptane," Journal of Bacteriology, vol. 182, no. 4, pp. 1158-1161, 2000.

[34] D. Bartig, K. Lemkemeier, J. Frank, F. Lottspeich, and F. Klink, "The archaebacterial hypusine-containing protein-structural features suggest common ancestry with eukaryotic translation initiation factor 5A," European Journal of Biochemistry, vol. 204, no. 2, pp. 751-758, 1992.

[35] N. Morimoto, W. Fukuda, N. Nakajima et al., "Dual biosynthesis pathway for longer-chain polyamines in the hyperthermophilic archaeon Thermococcus kodakarensis," Journal of Bacteriology, vol. 192, no. 19, pp. 4991-5001, 2010.

[36] K. Hamana, T. Tanaka, R. Hosoya, M. Niitsu, and T. Itoh, "Cellular polyamines of the acidophilic, thermophilic and thermoacidophilic archaebacteria, Acidilobus, Ferroplasma, Pyrobaculum, Pyrococcus, Staphylothermus, Thermococcus, Thermodiscus and Vulcanisaeta," Journal of General and Applied Microbiology, vol. 49, no. 5, pp. 287-293, 2003.

[37] A. J. Michael, "Polyamines in eukaryotes, bacteria, and archaea," The Journal of Biological Chemistry, vol. 291, no. 29, pp. 1489614903, 2016.

[38] P. Scherer and H. Kneifel, "Distribution of polyamines in methanogenic bacteria," Journal of Bacteriology, vol. 154, no. 3, pp. 1315-1322, 1983.

[39] K. Hamana, H. Hayashi, M. Niitsu, and T. Itoh, "Polyamine analysis of thermophilic, acidophilic, alkaliphilic and radiotolerant bacteria belonging to the domain bacteria and methanogens, thermophiles and extreme halophiles belonging to the domain archaea-polyamine catalogues of bacterial (eubacterial)," Journal of Japanese Society for Extremophiles, vol. 8, pp. 59-68, 2009.

[40] T. Tanaka, K. Hamana, and T. Itoh, "Polyamine analysis of extremely halophilic archaebacteria and methanogenic archaebacteria," Annals of Gunma University School of Health Sciences, vol. 23, pp. 137-143, 2002.

[41] K. Hamana, H. Hamana, and T. Itoh, "Ubiquitous occurrence of agmatine as the major polyamine within extremely halophilic archaebacteria," Journal of General and Applied Microbiology, vol. 41, no. 2, pp. 153-158, 1995.

[42] Y. Ikeuchi, S. Kimura, T. Numata et al., "Agmatine-conjugated cytidine in a tRNA anticodon is essential for AUA decoding in archaea," Nature Chemical Biology, vol. 6, no. 4, pp. 277-282, 2010.

[43] D. Mandal, C. Köhrer, D. Su et al., "Agmatidine, a modified cytidine in the anticodon of archaeal tRNA ${ }^{\text {Ile }}$, base pairs with adenosine but not with guanosine," Proceedings of the National Academy of Sciences of the United States of America, vol. 107, no. 7, pp. 2872-2877, 2010.

[44] I. K. Blaby, G. Phillips, C. E. Blaby-Haas, K. S. Gulig, B. El Yacoubi, and V. de Crécy-Lagard, "Towards a systems approach in the genetic analysis of archaea: accelerating mutant construction and phenotypic analysis in Haloferax Volcanii," Archaea, vol. 2010, Article ID 426239, 11 pages, 2010.

[45] K. Okada, R. Hidese, W. Fukuda et al., "Identification of a novel aminopropyltransferase involved in the synthesis of branched-chain polyamines in hyperthermophiles," Journal of Bacteriology, vol. 196, no. 10, pp. 1866-1876, 2014.

[46] M. Dyall-Smith, The Halohandbook: Protocols for Halobacterial Genetics, Version 7.2, 2009.

[47] T. Allers, H.-P. Ngo, M. Mevarech, and R. G. Lloyd, "Development of additional selectable markers for the halophilic archaeon haloferax volcanii based on the leuB and trpA genes," Applied and Environmental Microbiology, vol. 70, no. 2, pp. 943953, 2004.

[48] B. El Yacoubi, G. Phillips, I. K. Blaby et al., "A gateway platform for functional genomics in Haloferax volcanii: deletion of three tRNA modification genes," Archaea, vol. 2, no. 4, pp. 211-219, 2009.

[49] A. Large, C. Stamme, C. Lange et al., "Characterization of a tightly controlled promoter of the halophilic archaeon Haloferax volcanii and its use in the analysis of the essential cct1 gene," Molecular Microbiology, vol. 66, no. 5, pp. 1092-1106, 2007.

[50] J. Gebetsberger, M. Zywicki, A. Künzi, and N. Polacek, “TRNAderived fragments target the ribosome and function as regulatory non-coding RNA in Haloferax volcanii," Archaea, vol. 2012, Article ID 260909, 11 pages, 2012.

[51] H. V. Miranda, H. Antelmann, N. Hepowit et al., "Archaeal ubiquitin-like SAMP3 is isopeptide-linked to proteins via a UbaA-dependent mechanism," Molecular and Cellular Proteomics, vol. 13, no. 1, pp. 220-239, 2014.

[52] T. Oshima, "[68] Novel polyamines in Thermus thermophilus: isolation, identification, and chemical synthesis," Methods in Enzymology, vol. 94, no. C, pp. 401-411, 1983.

[53] L. Sanchez, TCA Protein Precipitation Protocol, 2001.

[54] P. K. Smith, R. I. Krohn, G. T. Hermanson et al., "Measurement of protein using bicinchoninic acid," Analytical Biochemistry, vol. 150, no. 1, pp. 76-85, 1985. 
[55] Y. Nishiki, T. B. Farb, J. Friedrich, K. Bokvist, R. G. Mirmira, and B. Maier, "Characterization of a novel polyclonal anti-hypusine antibody," SpringerPlus, vol. 2, article 421, 2013.

[56] A. Shevchenko, H. Tomas, J. Havliš, J. V. Olsen, and M. Mann, "In-gel digestion for mass spectrometric characterization of proteins and proteomes," Nature Protocols, vol. 1, no. 6, pp. 2856-2860, 2007.

[57] J. Rappsilber, Y. Ishihama, and M. Mann, "Stop and go extraction tips for matrix-assisted laser desorption/ionization, nanoelectrospray, and LC/MS sample pretreatment in proteomics," Analytical Chemistry, vol. 75, no. 3, pp. 663-670, 2003.

[58] S. F. Altschul, T. L. Madden, A. A. Schäffer et al., "Gapped BLAST and PSI-BLAST: a new generation of protein database search programs," Nucleic Acids Research, vol. 25, no. 17, pp. 3389-3402, 1997.

[59] F. Sievers and D. G. Higgins, "Clustal omega," Current Protocols in Bioinformatics, vol. 2014, pp. 3.13.1-3.13.16, 2014.

[60] F. Corpet, "Multiple sequence alignment with hierarchical clustering," Nucleic Acids Research, vol. 16, no. 22, pp. 1088110890, 1988.

[61] R. D. Finn, A. Bateman, J. Clements et al., "Pfam: the protein families database," Nucleic Acids Research, vol. 42, no. 1, pp. D222-D230, 2014.

[62] A. Krogh, B. Larsson, G. von Heijne, and E. L. L. Sonnhammer, "Predicting transmembrane protein topology with a hidden Markov model: application to complete genomes," Journal of Molecular Biology, vol. 305, no. 3, pp. 567-580, 2001.

[63] L. J. Jensen, M. Kuhn, M. Stark et al., "STRING 8-a global view on proteins and their functional interactions in 630 organisms," Nucleic Acids Research, vol. 37, supplement 1, pp. D412-D416, 2009.

[64] R. Overbeek, R. Olson, G. D. Pusch et al., "The SEED and the rapid annotation of microbial genomes using subsystems technology (RAST)," Nucleic Acids Research, vol. 42, no. 1, pp. D206-D214, 2014.

[65] W. Fukuda, N. Morimoto, T. Imanaka, and S. Fujiwara, "Agmatine is essential for the cell growth of Thermococcus kodakaraensis," FEMS Microbiology Letters, vol. 287, no. 1, pp. 113-120, 2008.

[66] A. L. Hartman, C. Norais, J. H. Badger et al., "The complete genome sequence of Haloferax volcanii DS2, a model archaeon," PLoS ONE, vol. 5, no. 3, Article ID e9605, 2010.

[67] S. Goda, H. Sakuraba, Y. Kawarabayasi, and T. Ohshima, "The first archaeal agmatinase from anaerobic hyperthermophilic archaeon Pyrococcus horikoshii: cloning, expression, and characterization," Biochimica et Biophysica Acta-Proteins and Proteomics, vol. 1748, no. 1, pp. 110-115, 2005.

[68] D. Miller, H. Xu, and R. H. White, "A new subfamily of agmatinases present in methanogenic archaea is Fe(II) dependent," Biochemistry, vol. 51, no. 14, pp. 3067-3078, 2012.

[69] T. Fukui, H. Atomi, T. Kanai, R. Matsumi, S. Fujiwara, and T. Imanaka, "Complete genome sequence of the hyperthermophilic archaeon Thermococcus kodakaraensis $\mathrm{KOD}_{1}$ and comparison with Pyrococcusgenomes," Genome Research, vol. 15, no. 3, pp. 352-363, 2005.

[70] M. Burrell, C. C. Hanfrey, L. N. Kinch, K. A. Elliott, and A. J. Michael, "Evolution of a novel lysine decarboxylase in siderophore biosynthesis," Molecular Microbiology, vol. 86, no. 2, pp. 485-499, 2012.

[71] H. Tokunaga, S. Hara, T. Arakawa, M. Ishibashi, R. S. Gupta, and M. Tokunaga, "Identification and partial purification of DnaK homologue from extremely halophilic archaebacteria,
Halobacterium cutirubrum," Journal of Protein Chemistry, vol. 18, no. 8, pp. 837-844, 1999.

[72] H. Tokunaga, T. Arakawa, and M. Tokunaga, "Engineering of halophilic enzymes: Two acidic amino acid residues at the carboxy-terminal region confer halophilic characteristics to halomonas and pseudomonas nucleoside diphosphate kinases," Protein Science, vol. 17, no. 9, pp. 1603-1610, 2008.

[73] D. Madern, C. Ebel, and G. Zaccai, "Halophilic adaptation of enzymes," Extremophiles, vol. 4, no. 2, pp. 91-98, 2000.

[74] B.-F. Jin, K. He, H.-X. Wang et al., "Proteomic analysis of ubiquitin-proteasome effects: insight into the function of eukaryotic initiation factor 5A," Oncogene, vol. 22, no. 31, pp. 4819-4830, 2003.

[75] Y. Shang, X. Zhao, B. Tian et al., "CHIP/Stub1 interacts with eIF5A and mediates its degradation," Cellular Signalling, vol. 26, no. 5, pp. 1098-1104, 2014.

[76] E. D. Gordon, R. Mora, S. C. Meredith, and S. L. Lindquist, "Hypusine formation in eukaryotic initiation factor $4 \mathrm{D}$ is not reversed when rates or specificity of protein synthesis is altered," The Journal of Biological Chemistry, vol. 262, no. 34, pp. 1659016595, 1987.

[77] R. F. Duncan and J. W. B. Hershey, "Changes in eIF-4D hypusine modification or abundance are not correlated with translational repression in HeLa cells," Journal of Biological Chemistry, vol. 261, no. 27, pp. 12903-12906, 1986.

[78] K. Hamana, M. Kamekura, H. Onishi, T. Akazawa, and S. Matsuzaki, "Polyamines in photosynthetic eubacteria and extremehalophilic archaebacteria," Journal of Biochemistry, vol. 97, no. 6, pp. 1653-1658, 1985.

[79] M. Kamekura, S. Bardocz, P. Anderson, R. Wallace, and D. J. Kushner, "Polyamines in moderately and extremely halophilic bacteria," BBA - General Subjects, vol. 880, no. 2-3, pp. 204-208, 1986.

[80] K. Hamana and M. Takeuchi, "Polyamine profiles as chemotaxonomic marker within Alpha, Beta, Gamma, Delta, and Epsilon subclasses of class proteobacteria: distribution of 2hydroxyputrescine and homospermidine," Microbiology and Culture Collections, vol. 14, pp. 1-14, 1998.

[81] A. Bouchereau, A. Aziz, F. Larher, and J. Martin-Tanguy, "Polyamines and environmental challenges: recent development," Plant Science, vol. 140, no. 2, pp. 103-125, 1999.

[82] H. Samartzidou, M. Mehrazin, Z. Xu, M. J. Benedik, and A. H. Delcour, "Cadaverine inhibition of porin plays a role in cell survival at acidic pH," Journal of Bacteriology, vol. 185, no. 1, pp. 13-19, 2003.

[83] I. K. Blaby, M. Majumder, K. Chatterjee et al., "Pseudouridine formation in archaeal RNAs: the case of Haloferax volcanii," RNA, vol. 17, no. 7, pp. 1367-1380, 2011.

[84] D.-I. Liao, E. C. Wolff, M. H. Park, and D. R. Davies, "Crystal structure of the NAD complex of human deoxyhypusine synthase: an enzyme with a ball-and-chain mechanism for blocking the active site," Structure, vol. 6, no. 1, pp. 23-32, 1998.

[85] D. Ober and T. Hartmann, "Deoxyhypusine synthase from tobacco. cDNA isolation, characterization and bacterial expression of an enzyme with extended substrate specificity," Journal of Biological Chemistry, vol. 274, no. 45, pp. 32040-32047, 1999.

[86] E. C. Wolff, Y. B. Lee, S. I. Chung, J. E. Folk, and M. H. Park, "Deoxyhypusine synthase from rat testis: purification and characterization," The Journal of Biological Chemistry, vol. 270, no. 15 , pp. 8660-8666, 1995. 

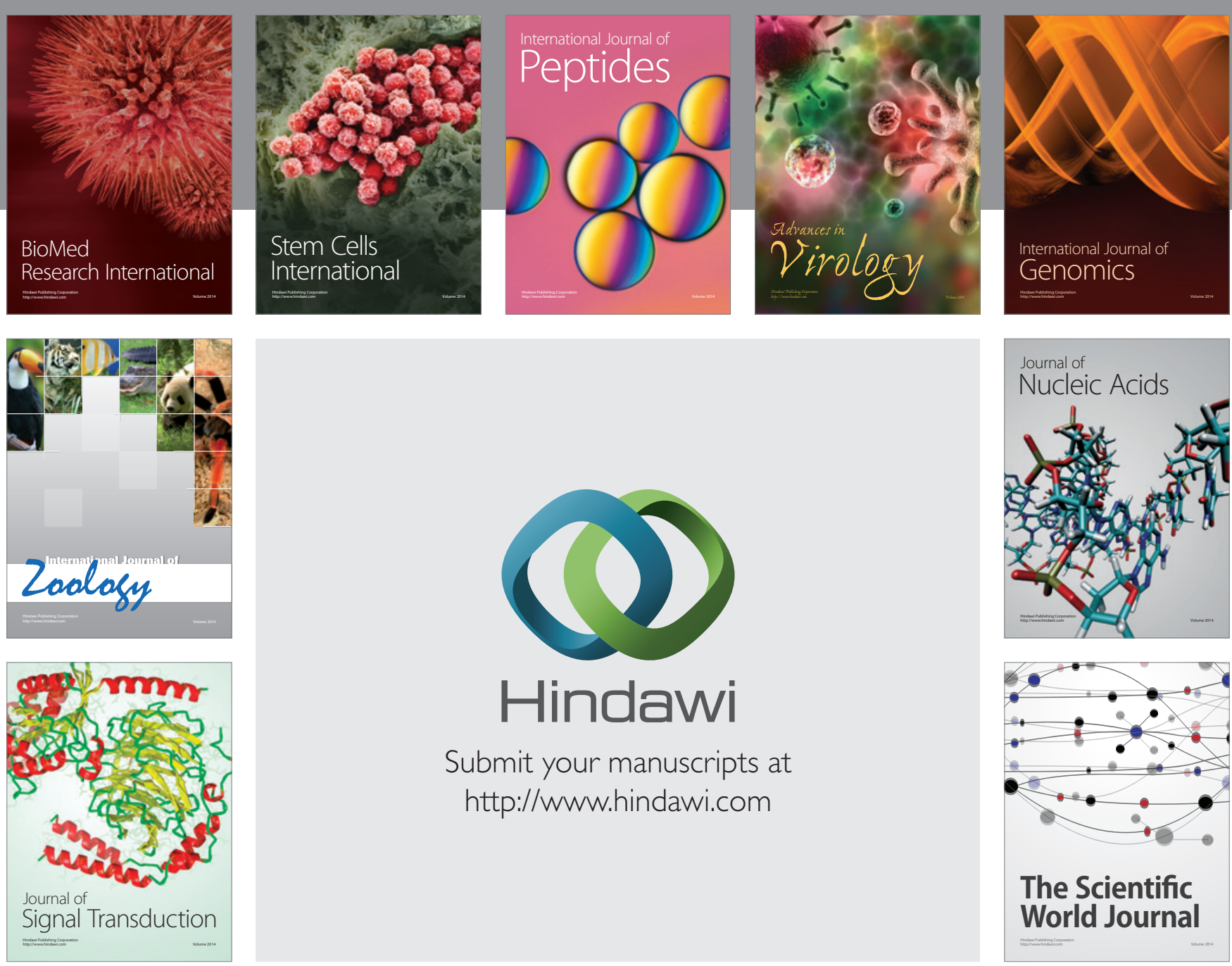

Submit your manuscripts at

http://www.hindawi.com
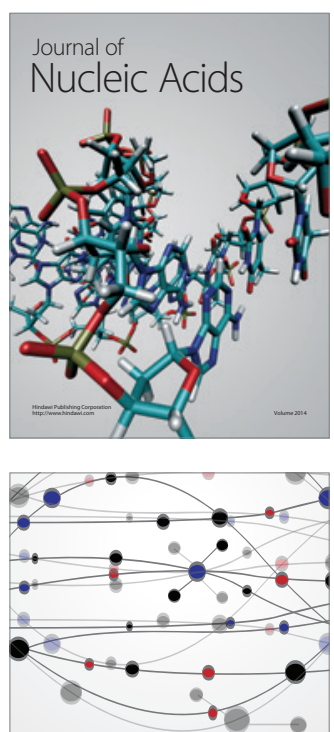

The Scientific World Journal
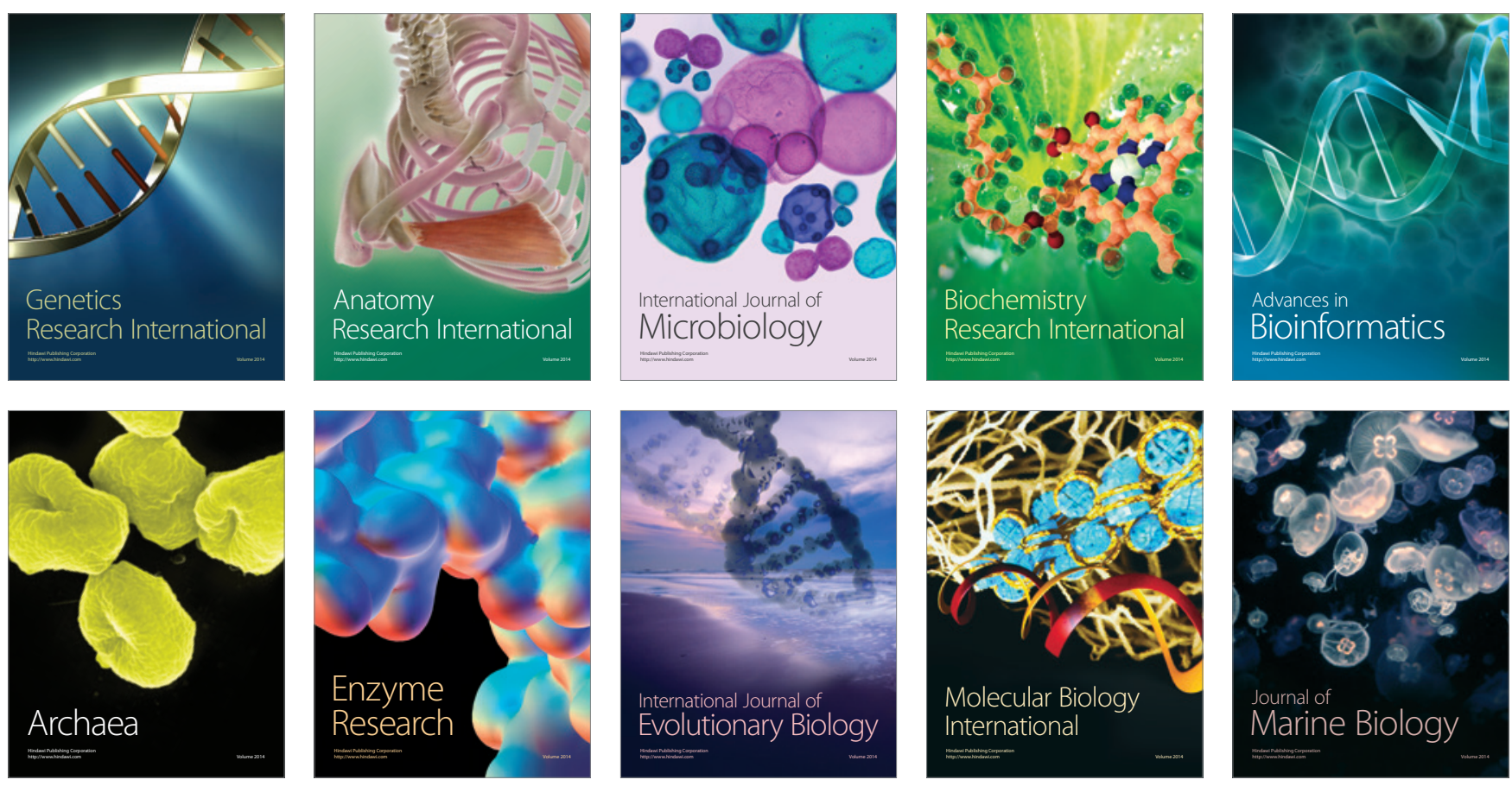